\title{
CREDIT WORTHINESS OF SOME FARMERS IN NUBARIA
}

\author{
ABD EL-SALAM, KHALED AZIZ and MOHAMED HASSAN AHMED \\ Agricultural Finance and Cooperation Research Department, Agricultural Economics \\ Research Institute, ARC
}

(Manuscript received 12 February 2019)

\begin{abstract}
A gricultural credit plays an important and, indeed, crucial role in solving many of the difficult problems faced by farmers, especially their young ones, where financing is the mainstay of agricultural investment. The research problem is the high level of financing requirements in the new lands, in addition to some economic problems facing the agricultural sector in general and the new lands in particular. The objective of the research is to determine the creditworthiness of a sample of farmers in the new lands and to determine their ability to achieve a return that allows the repayment of the loan Its cost, and increase the net income of the borrower. As well as to identify the social and economic characteristics of the sample of the research, and identify the most important financing problems facing the new land farmers, and how to overcome them. The results showed that the increase in the volume of loans to cover the costs had a positive effect on the productivity of acres of crops. The ratio of debt coverage to the total average yield of field crops was achieved more than once, covering about 1.4 of the total debt. The yield of vegetable crops achieved more than twice, about 2.2of the total debt. As for the ratio of debt coverage to the total average yield of fruit crops, it achieved three times, about 3.3 of total debt. That is, all crops have a return that covers the required debt, ie, they have a high credit capacity. Although the bank is vulnerable to high risk loans, it does not cover the total return of crops by $100 \%$ although all the sample has guarantees other than crop yield, which makes them have credit capacity exceeding $100 \%$ of their crop yield. To cover the bank debt from the net yield of crops.
\end{abstract}




\title{
القدرة الانتمانية لبعض المزارعين بمنطقة النوبارية
}

\author{
خالد عزيز عبد السدام أحمد ، محمد حسن أحمد على
}

قسم بحوث التمويل والتعاون الزر اعىـ معهد بحوث الاقتصاد الزراعىـ مركز البحوث الزراعية

\section{مقدمـة}

يعتبر القطاع الزر اعى فى مصر من القطاعات الاقتصادية الهامة فى تحقيق التتمية الاقتصادية

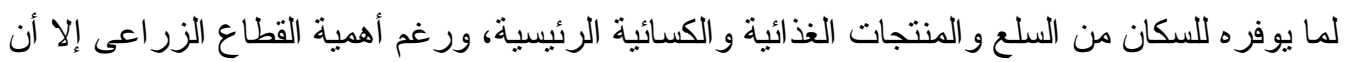

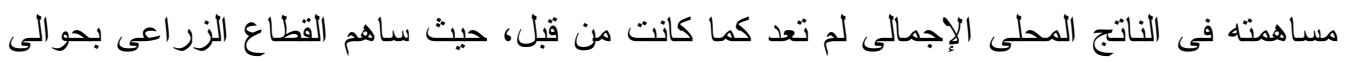

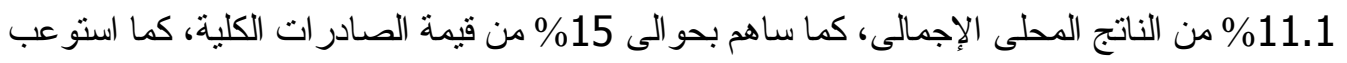

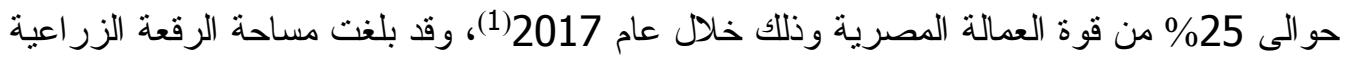

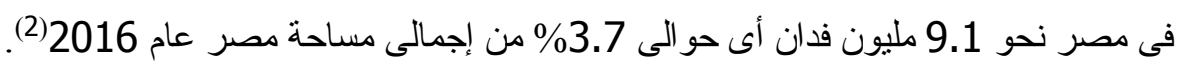

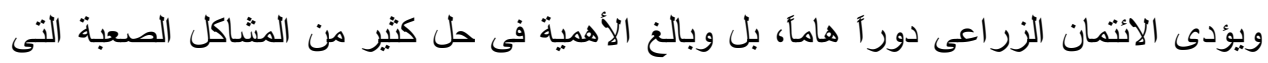

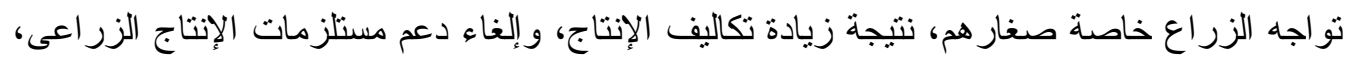

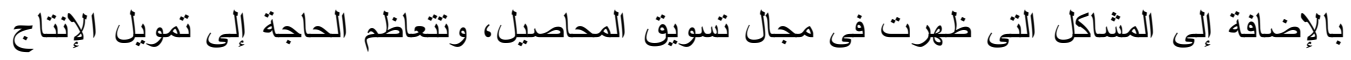

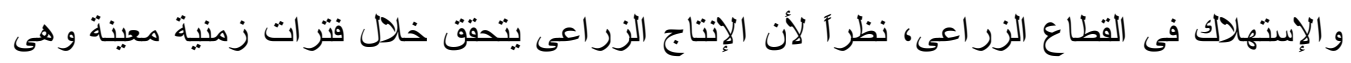

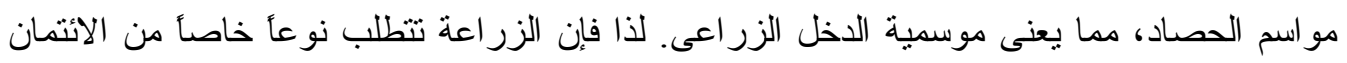

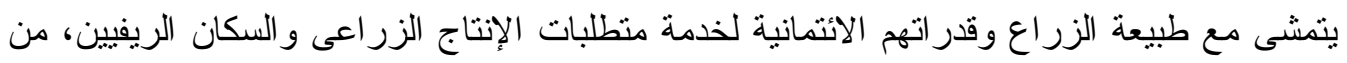

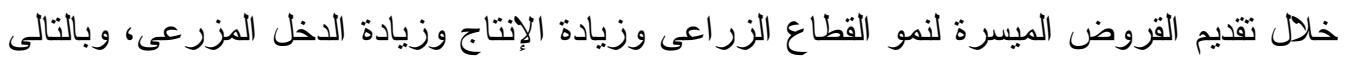

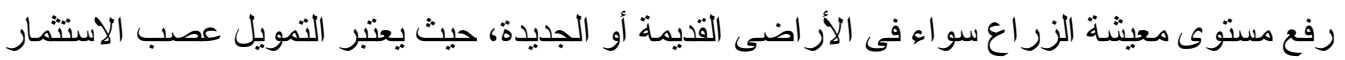
الزر اعى، و المحدد الرئيسى لتحقيق معدلات عالية فى التتمبة الزر اعية(3).

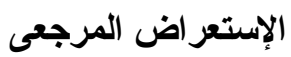

فى دراسة لبكرى عام 1988 أوضحت أن أهم معوقات تحقيق التتمية الزراعية بالأر اضى الأنى

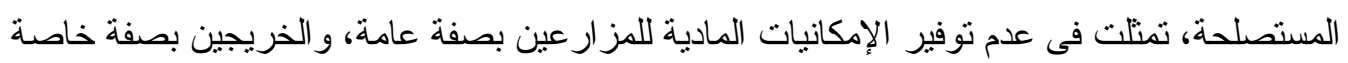

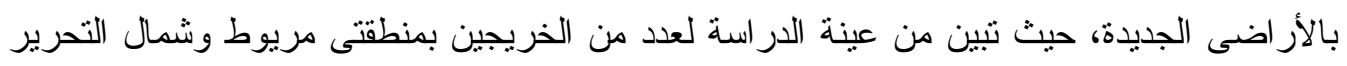

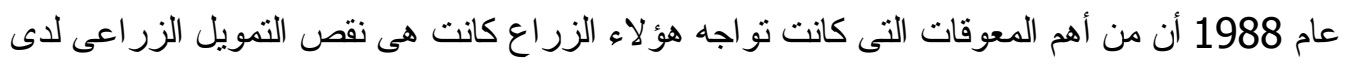

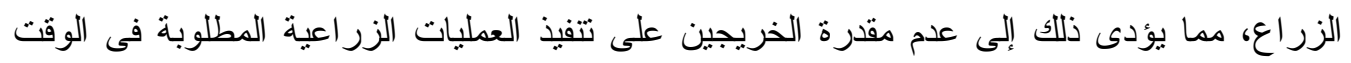

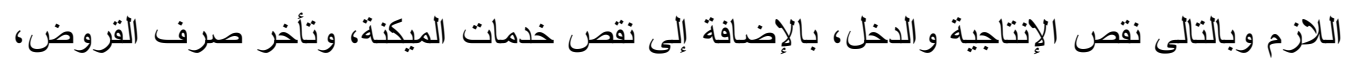
ونقص مستلزمات الإنتاج، وضعف الجهاز التسويقى التعاونى.

وفى در اسة لإلهام يونس عام 2003 تتاولت قياس الكفاءة الاقتصادية و الإنتاجية لبعض الإنس المحاصيل

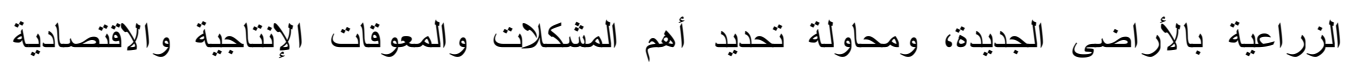

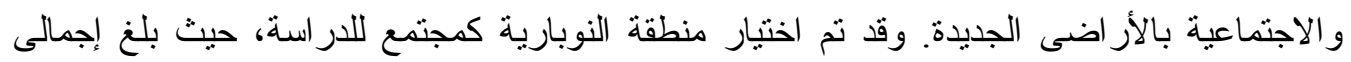

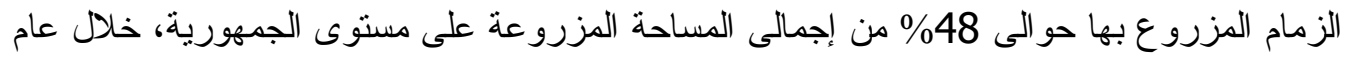

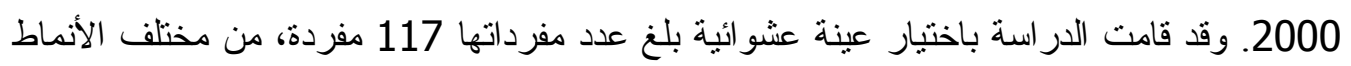

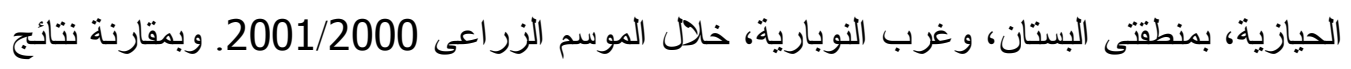

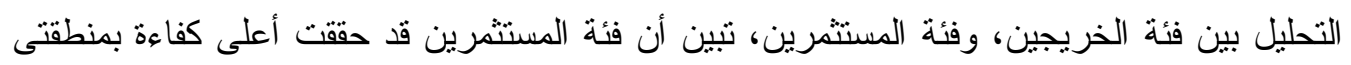




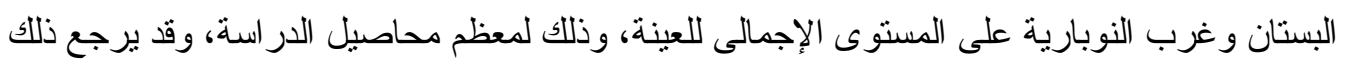

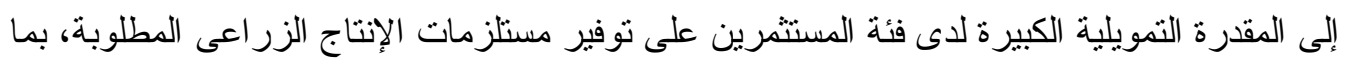

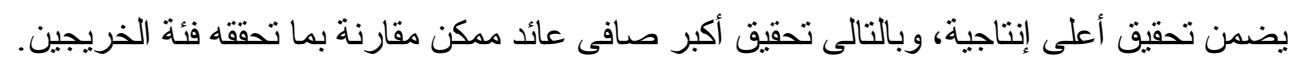

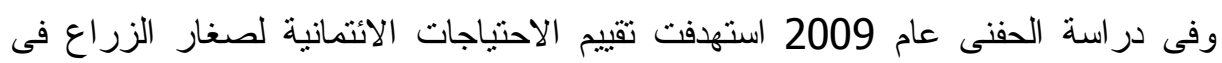

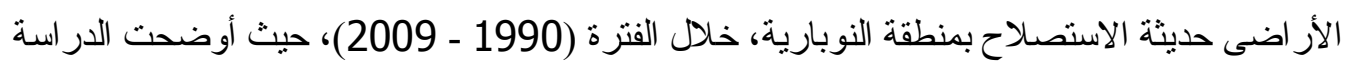

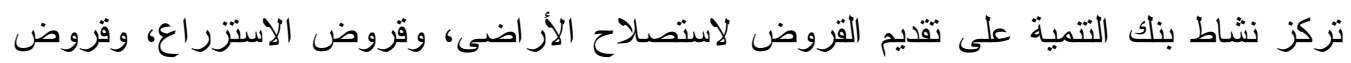

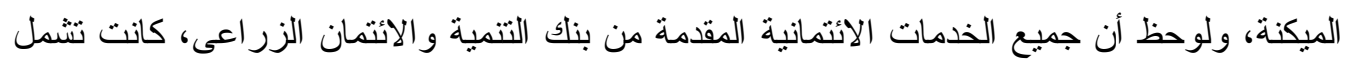

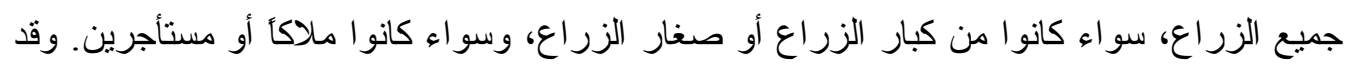

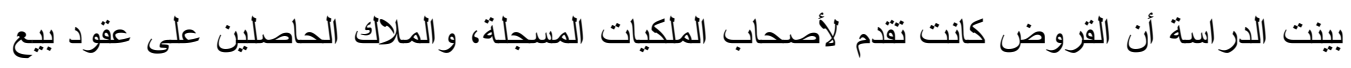

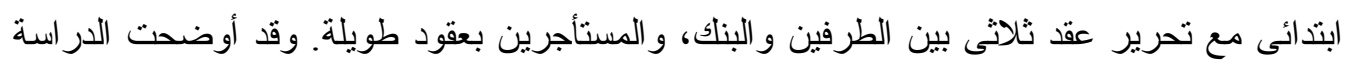

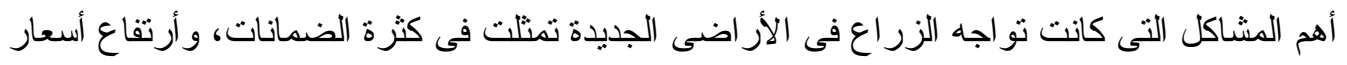

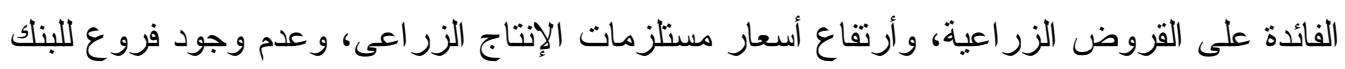

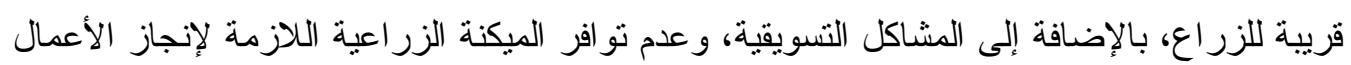

\section{مشكلة البحث}

المزر عية.

تتمنل مشكلة البحث فى إرتفاع المتطلبات التمويلية فى الأراضى الجديدة من ناحية، بالإضافة

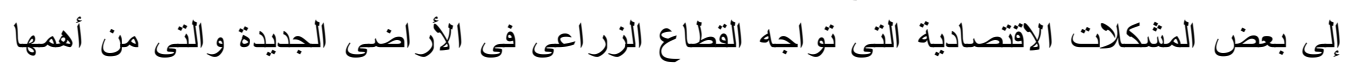

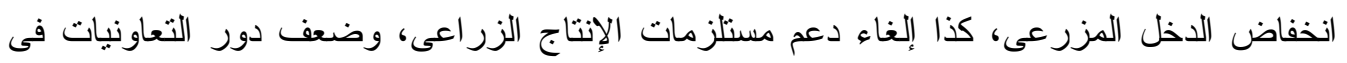

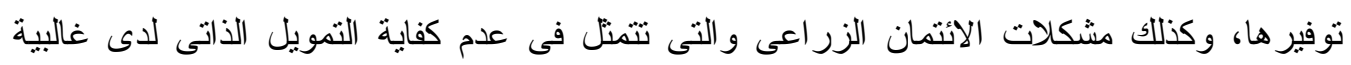

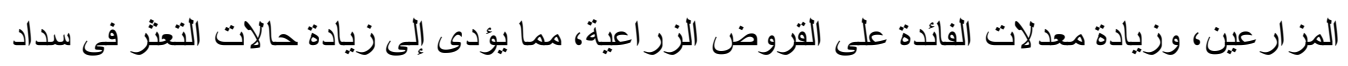

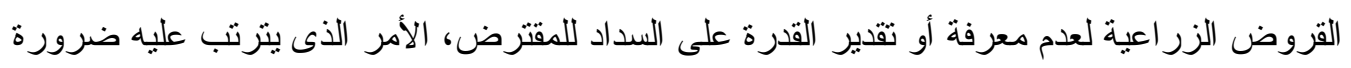

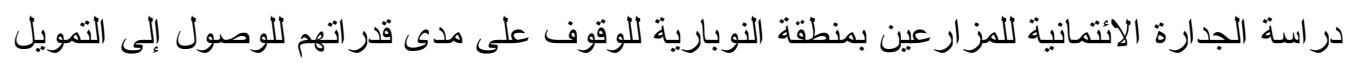

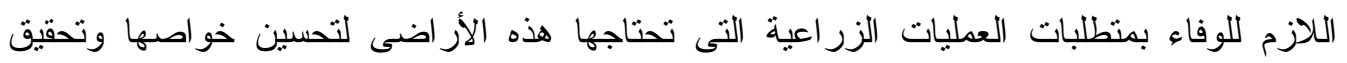
المستوى الإنتاجى الذى يؤدى إلى رفع الكفاءة الاقتصادية. أهداف البحث

وفى إطار التشخيص السابق للمشكلة فإن البحث يهدف إلى دراسة الجدارة الائتمانية لعينة من

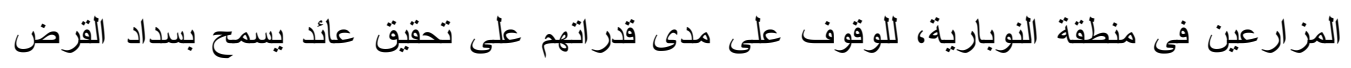

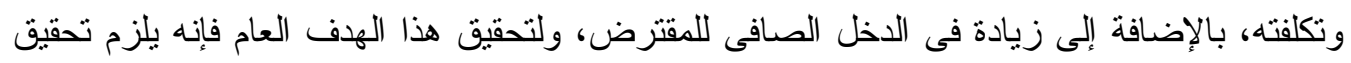

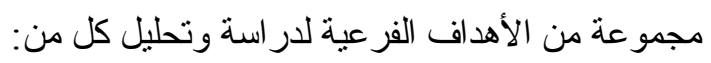

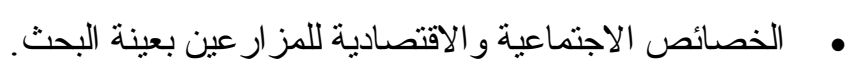

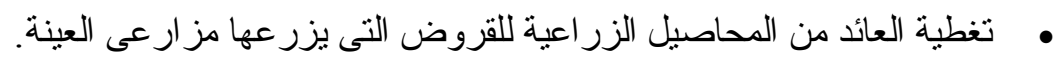

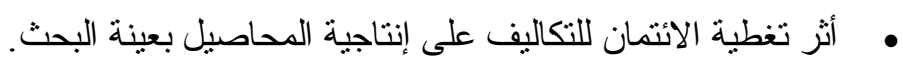

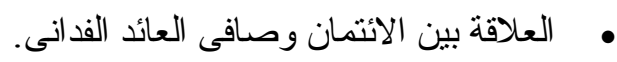

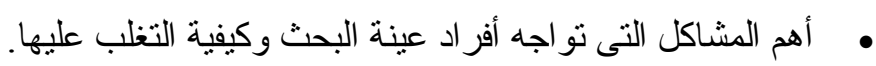

مصادر البيانات و الأسلوب البحثى البنى

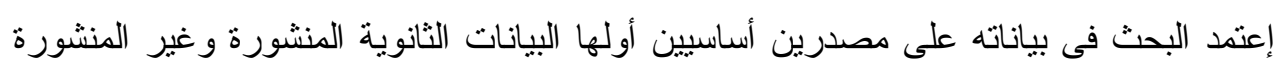

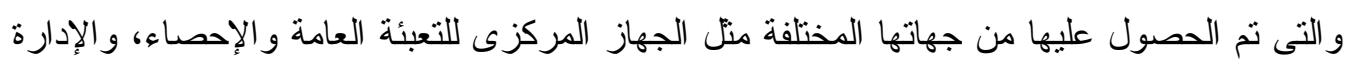


المركزية للاقتصاد الزراعى، وزارة الزراعة واستصلاح الأراضى، و البنك الزراعى المصرى،

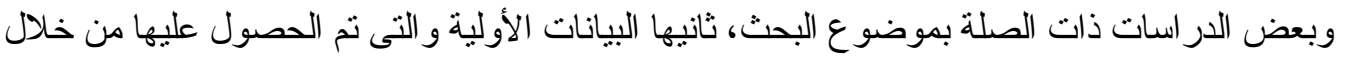

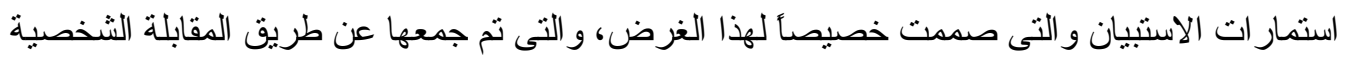
لبعض المز ارعين بمنطقة النوبارية. كما إعتمد البحث على بعض طرق التحليل بلئ الاقتصادى الوصفى و الكمى، وبعض أساليب التحليل

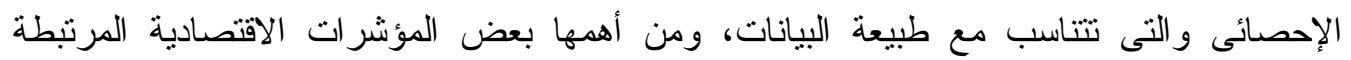

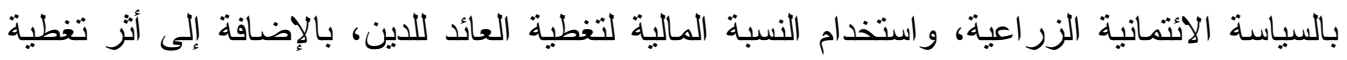

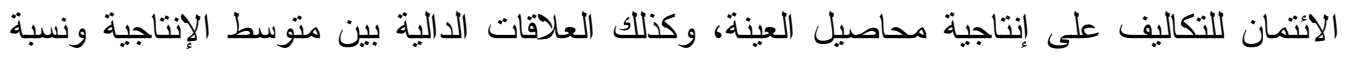
تغطية القروض الفدانية للتكاليف المتغيرة الفدانية لمحاصيل العينة. عينة البحث

أجريت الدراسة الميدانية بمنطقة النوبارية والنى تمنل حوالى 71\% من إجمالى المساحة

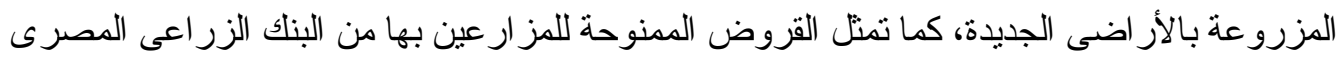

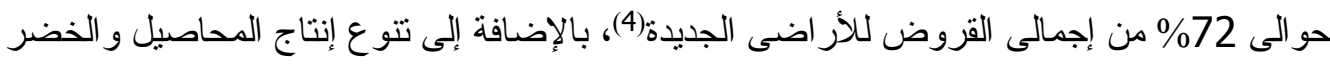

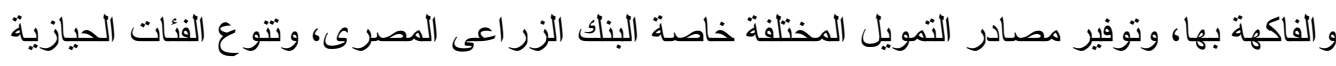
المستهدف دراستهم، وتبلغ جملة مساحة منطقة غرب النوبارية نحو 60 ألف فدان، ويتبعها أربعة وتهية

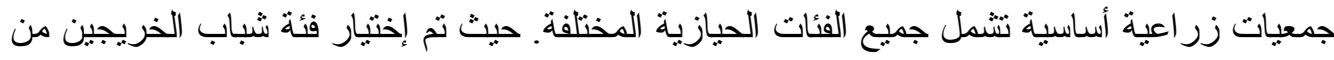

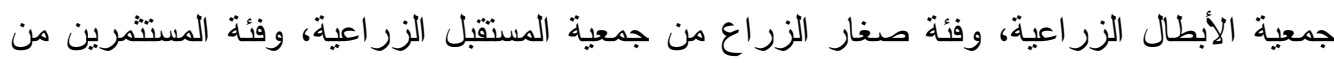
جمعية الثجاعة الزر اعية. وقد تم اختبار أفر اد مز ارعى العينة بطريقة عشو ائية من سجلات 2 خدمات بالجمعيات الزر اعية

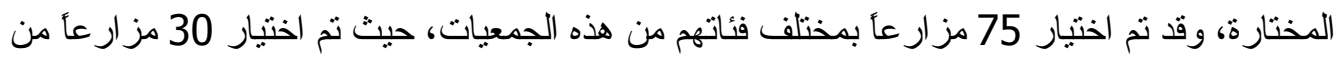

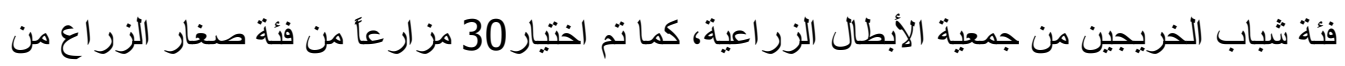

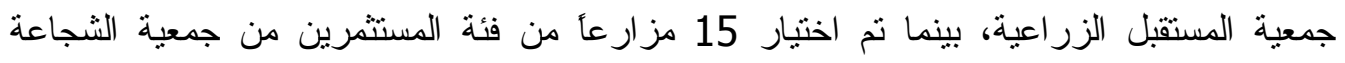
الزر اعية. باعتبار أن ذلك التوزيع لمفردات العينة تمثل مجتمع الدر اسة تمثيلا إحصائياً.

\section{نتائج البحث}

أولاً: الخصائص الاجتماعية والاقتصادية للمبحوثين بعينة البحث:

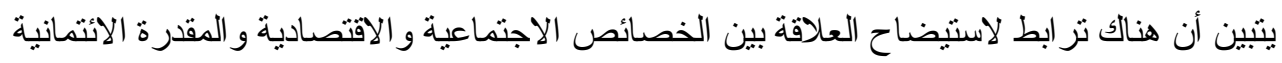

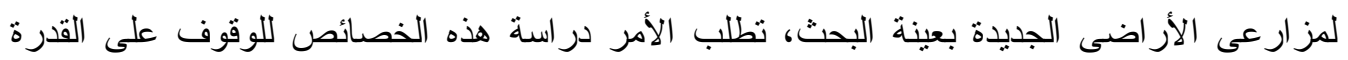
الايتمانية و العو امل المؤثزة عليها.

أ: الخصائص الاجتماعية:

1- توزيع المزارعين (أو المبحوثين) فى عينة البحث وفقاً للفئات العمرية:

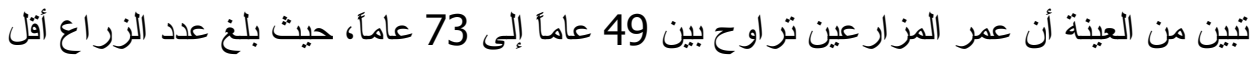

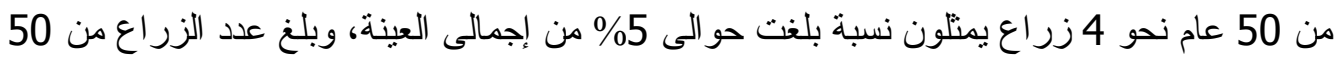

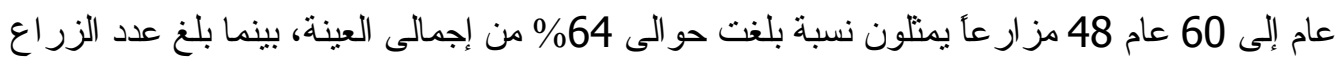

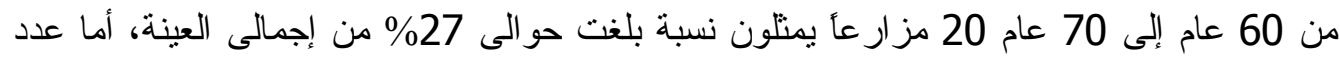

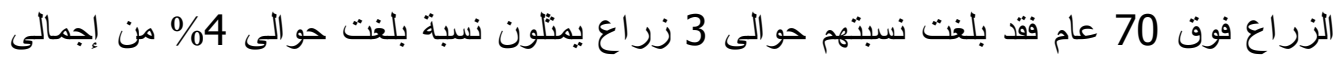

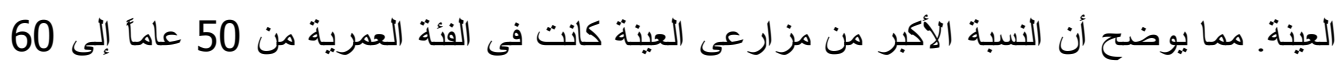

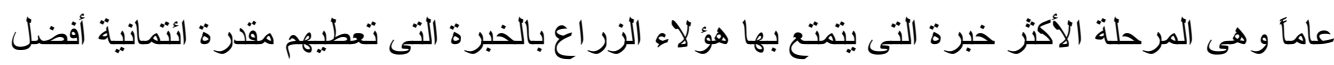


حيث تتو افر لديهم المعرفة اللازمة لتحقيق صافى عائد أفضل من الأنشطة الزر اعية، وبالرغم من ذلك هم أقل اتجاهأ للحصول على القروض من الفئة الأقل عمر آ. 2- توزيع المزارعين (أو المبحوثين) فى عينة البحث وفقاً للحالة التعليمية:

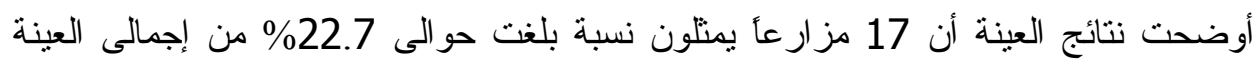

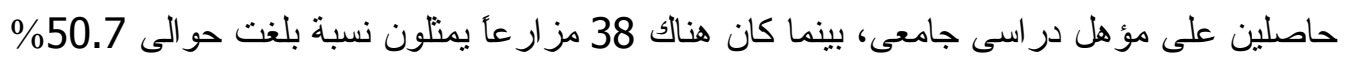

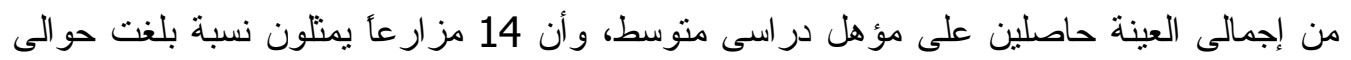

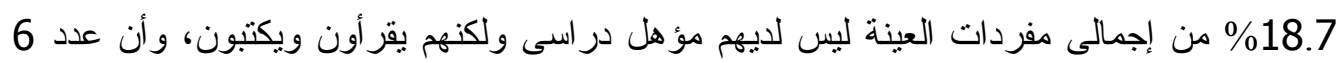

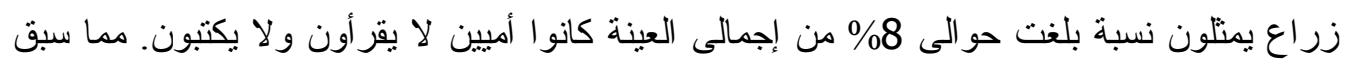

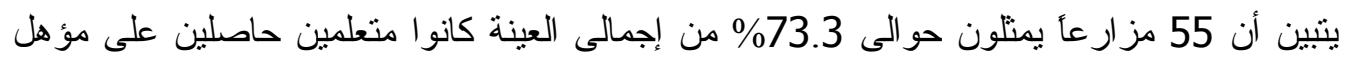

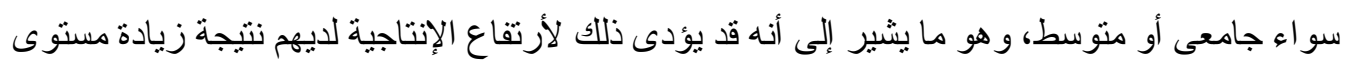

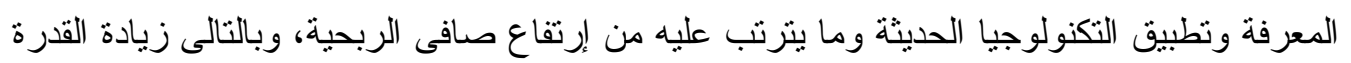
الائتمانية لايهم.

3- توزيع المزارعين (أو المبحوثين) فى عينة البحث وفقاً للحالة الاجتماعية، وعدد أفراد الأسرة:

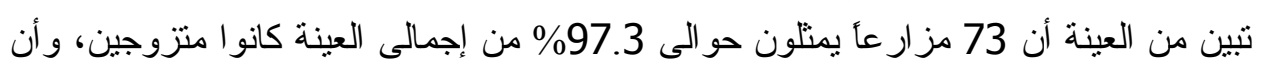
أثثين فقط يمثلون حو الى 2.7\% من إجمالى العينة كانو ا غير متزوجين. أما بالنسبة لعدد أفر اد الأسرة

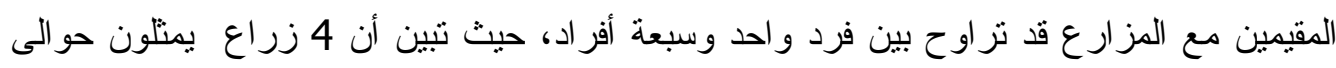

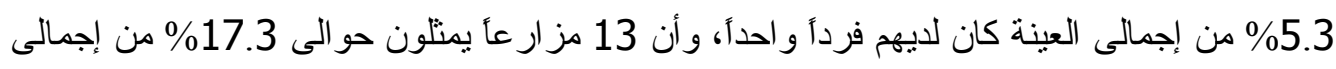

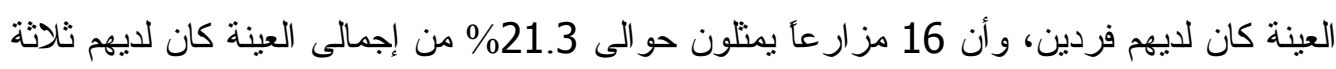

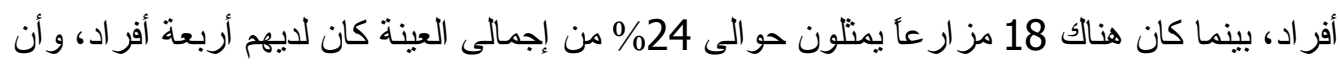

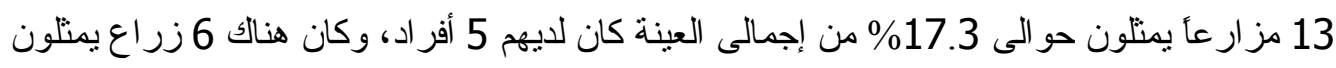

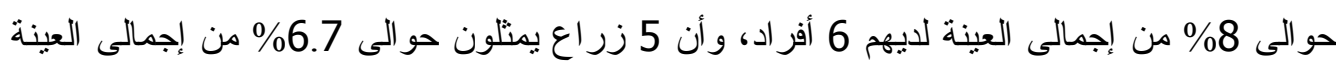

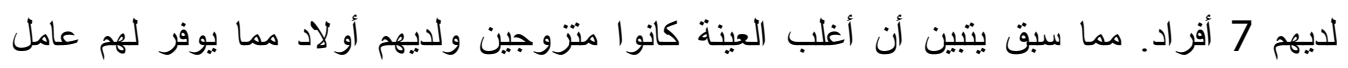

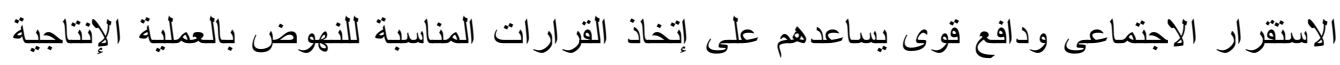

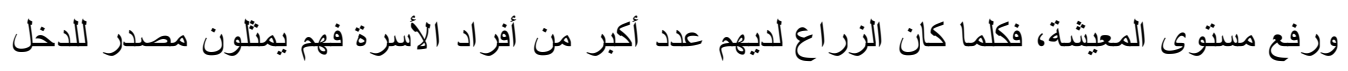

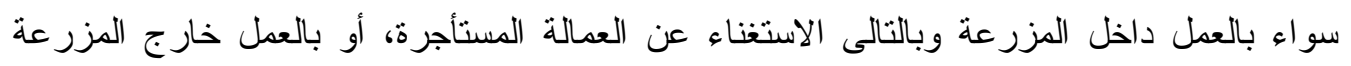

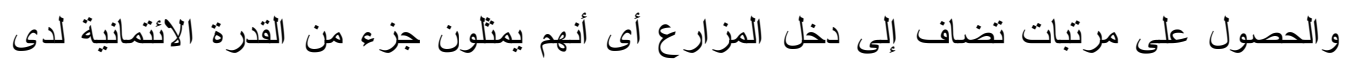

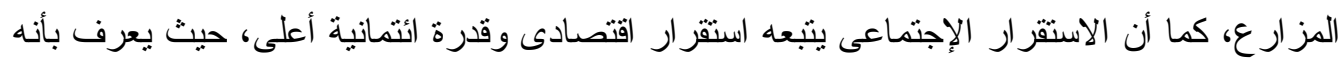

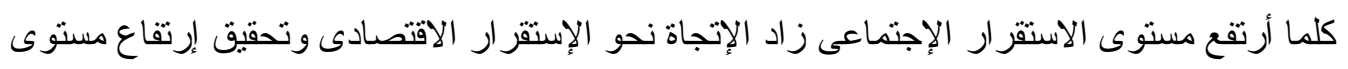
مقدرة وجدارة أكبر. ب: الخصائص الاقتصادية لمزارعى العينة: 1- توزيع المزارعين (أو المبحوثين) فى عينة البحث وفقاً لنوع العمل المزرعى: المينة:

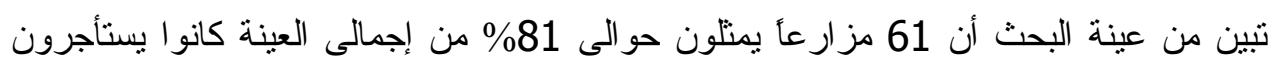

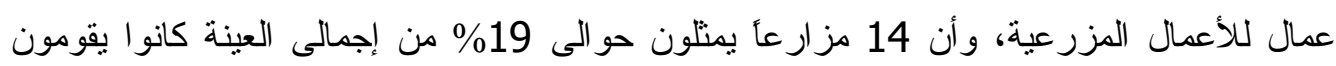

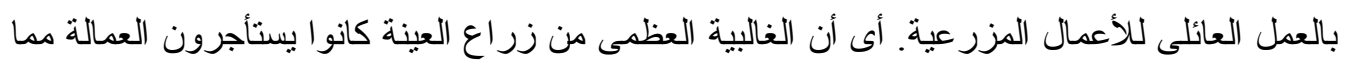

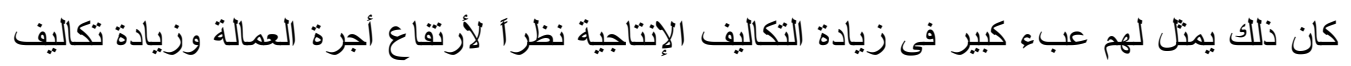

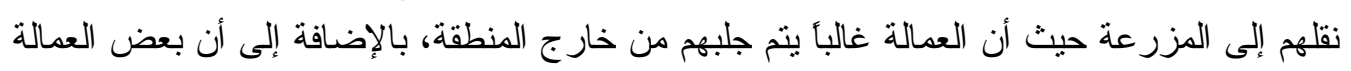




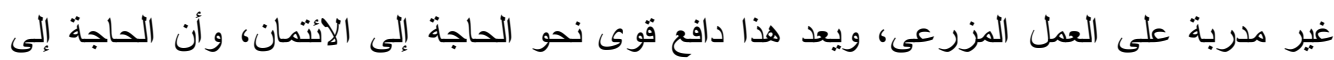

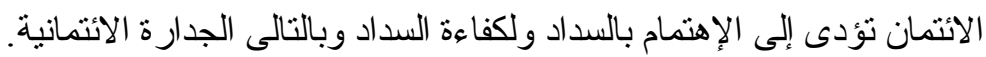

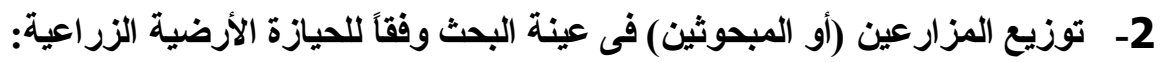

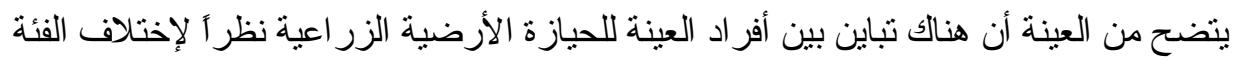

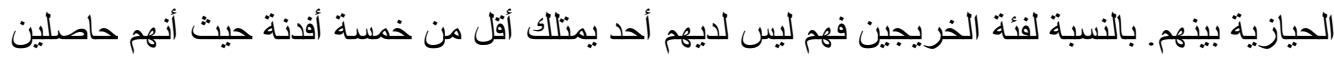

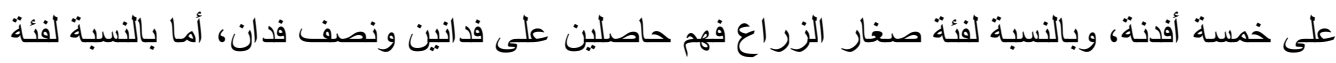

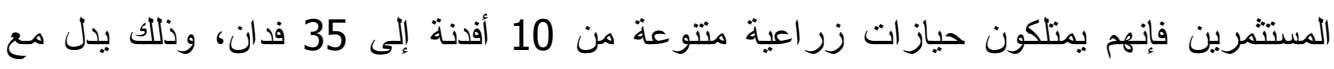
الإستقر ار التملكى للحبازة الأرضية الزراعية الذى تؤدى إلى قوة الضمانات وبالتالى رفع القدرة

3- توزيع المزارعين (أو المبحوثين) فى عينة البحث وفقاً لحيازة الأصول المزرعية:

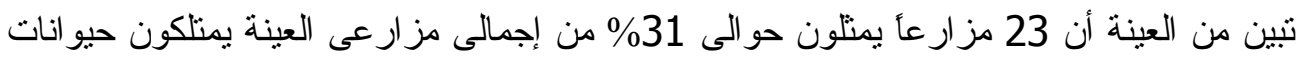
زر اعية، بينما أن 43 مز ارعأ يمتلون حو الى 57\% من إجمالى مز ارعى العينة يمتلكون آلات زر اعية.

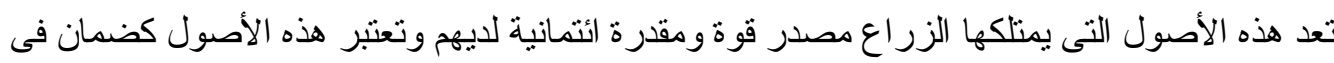

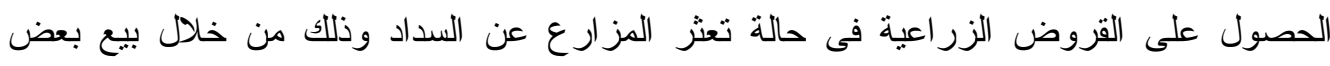
الحيو انات، والتخلب على نقص التمويل الذاتى بالحصول على دخل شبة يومى من فئل بيع المنتجات

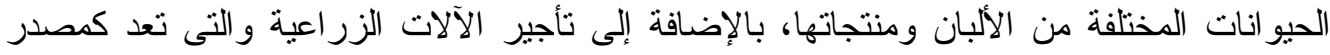

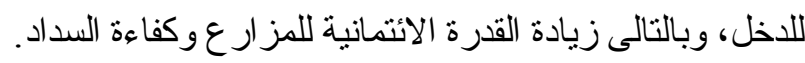

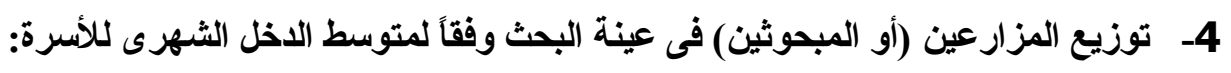

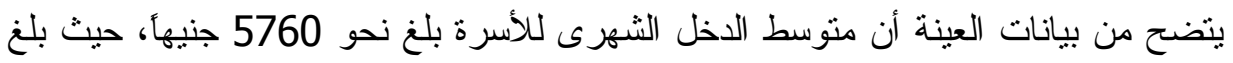

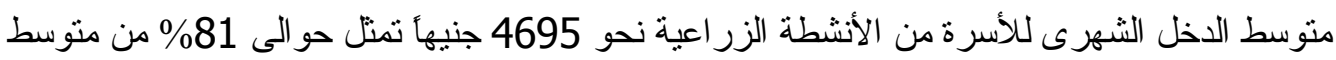

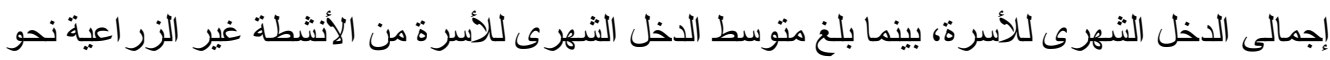

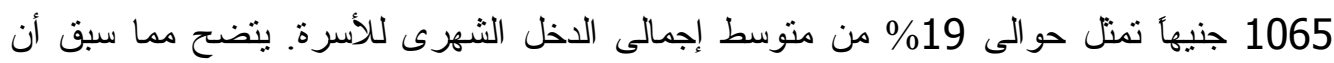

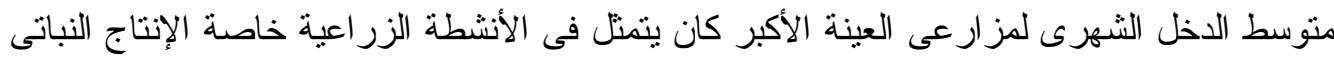

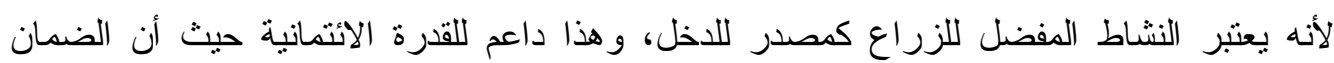
الأساسى للعملية الائتمانية هى الأنشطة الزر اعية. جدول رقم (1): متوسط الاخل الثهرى للأسرة لأى أفراد العينة.

\begin{tabular}{|c|c|c|}
\hline$\%$ & متوسط الدخل الثهرى & مصدر الدخل \\
\hline 81 & 4695 & من الأنشطة الزر اعية \\
\hline 19 & 1065 & من الأنشطة غبر الزر اعية \\
\hline 100.0 & 5760 & الإجمالى \\
\hline
\end{tabular}

المصدر : جمعت وحسبت من بيانات الاستبيان بعينة البحث.

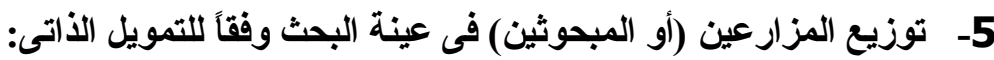

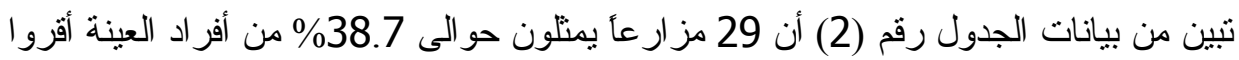

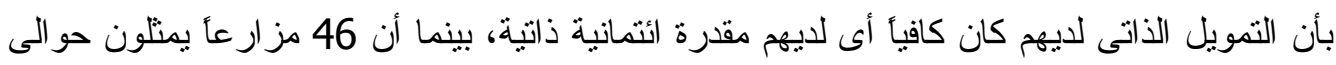
61.3\% من أفراد العينة أقروا بأن التمويل الذاتى لديهم كان غير كافياً. ويرجع ذللك إلى زيادة أسعار

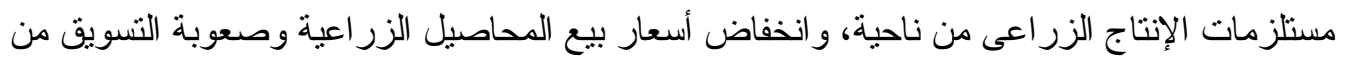


ناحية أخرى، وبالتالى انخفاض صافى الدخل المزارعى أى أنهم يحتاجون إلى تمويل خارجى ليساعدهم فى تمويل العمليات المزرعية.

جدول رقم (2): مدى كفاية التمويل الأتى لاى أفراد العينة.

\begin{tabular}{|c|c|c|}
\hline$\%$ & العدد & كفاية التمويل الذاتى \\
\hline 38.7 & 29 & كافى \\
\hline 61.3 & 46 & غير كافى \\
\hline 100.0 & 75 & الإجمالى \\
\hline
\end{tabular}

المصدر: جمعت وحسبت من بيانات الاستبيان بعينة البحث.

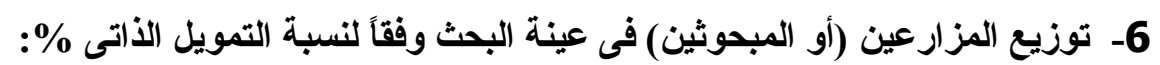

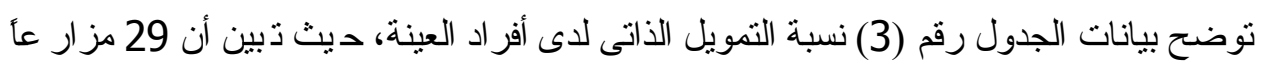

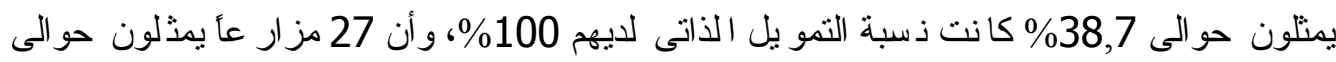

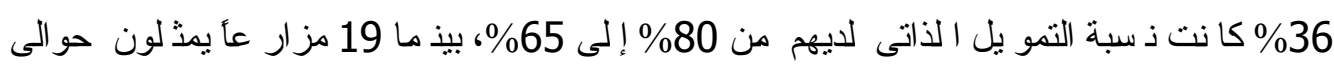

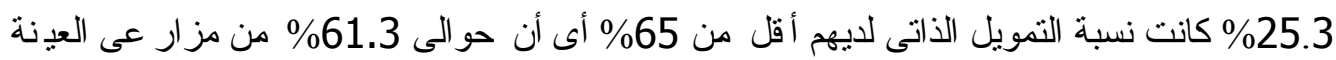

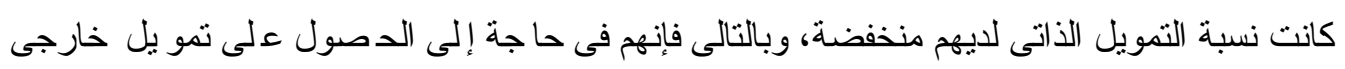

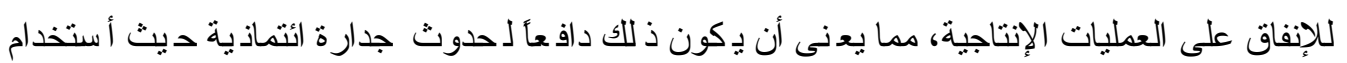
القروض فى مجالها وسد ادها يعد كفاءة إنتاجية منها.

جدول رقم (3): نسبة التمويل الأتى لأفر اد العينة.

\begin{tabular}{|c|c|c|}
\hline$\%$ & العدد & نسبة التمويل الذاتى \\
\hline 38.7 & 29 & 100 \\
\hline 36.0 & 27 & $65-80$ \\
\hline 25.3 & 19 & أقل من 65 \\
\hline 100.0 & 75 & الإجمالى \\
\hline
\end{tabular}

المصدر: جمعت وحسبت من بيانات الاستبيان بعينة البحث.

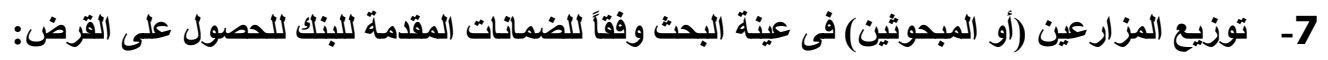

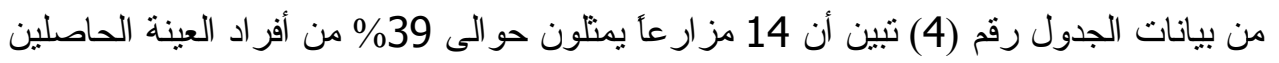

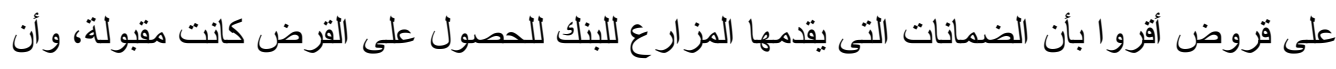

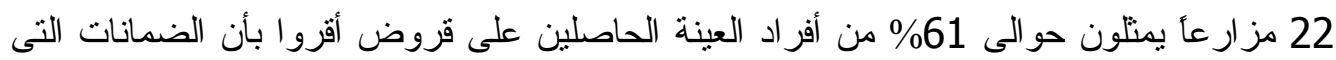

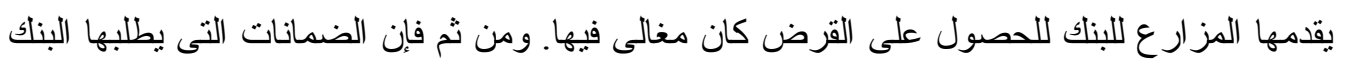

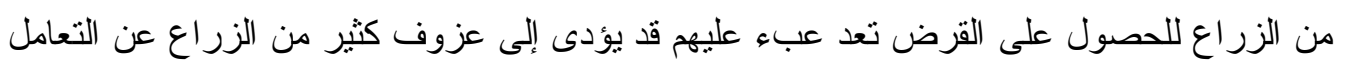

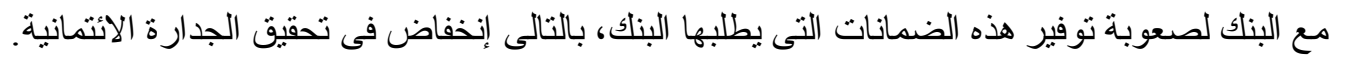

\begin{tabular}{|c|c|c|}
\hline$\%$ & العدد & الضمانات \\
\hline 38.9 & 14 & مقبولة \\
\hline 61.1 & 22 & مغالى فيها \\
\hline 100.0 & 36 & الإجمالى \\
\hline
\end{tabular}

المصدر : جمعت وحسبت من بياتات الاستبيان بعينة البحث. 
8- الضمانات التى يطلبها البنك:

تشير بيانات الجدول رقم (5) أن إجمالى أفر اد العينة الحاصلين على قروض و عددهم 36 مز ار عأ

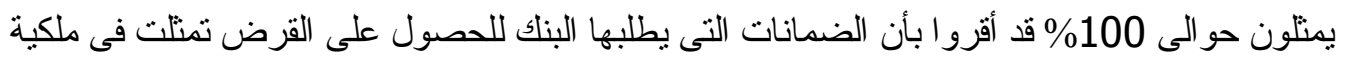

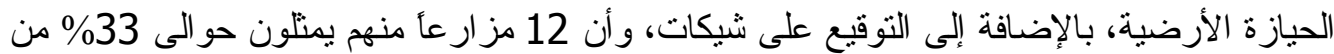

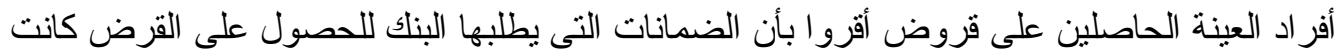

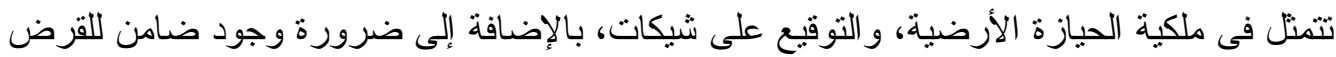

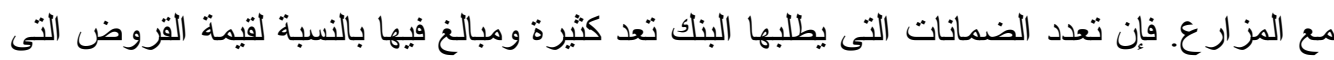

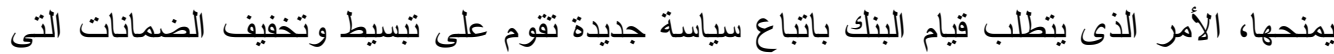
يطلبها البنك و التى قد تعد عائقاً أمام الكثير من المز ارعين خاصة صغار هم الذين لا تتو افر لديهم كافة

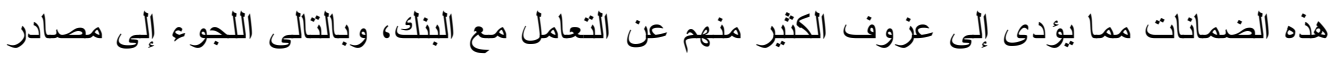

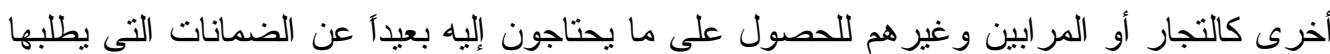

جدول رقم (5): نوعية الضمانات التى يطلبها البنك.

\begin{tabular}{|c|c|c|}
\hline$\%$ & العدد & الضمانات المطلوبة \\
\hline 66.7 & 24 & حيازة الأرض + التوقيع على شيكات \\
\hline 33.3 & 12 & حيازة الأرض + التوقيع على شيكات + ضامن للقرض \\
\hline 100.0 & 36 & 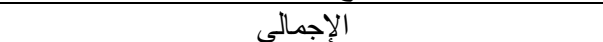 \\
\hline
\end{tabular}

المصدر : جمعت وحسبث من بيانات الاستبيان بعينة البحث.

$$
\text { 9- الحصول على القروض الزراعية: }
$$

تثنير بيانات الجدول رقم (6) أن 36 مزارعأ يمنلون حو الى 48\% من أفر اد عينة البحث قد

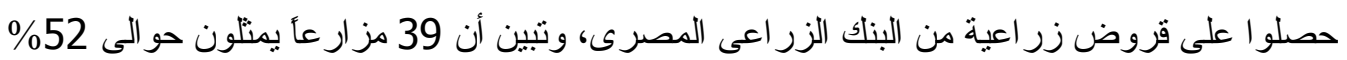

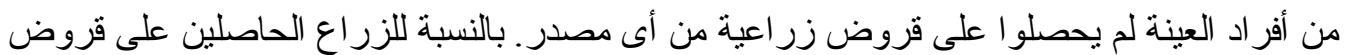

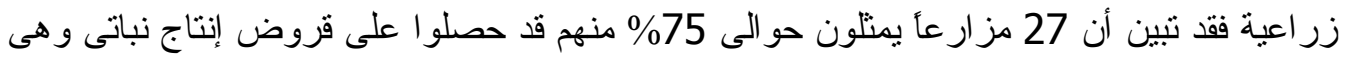

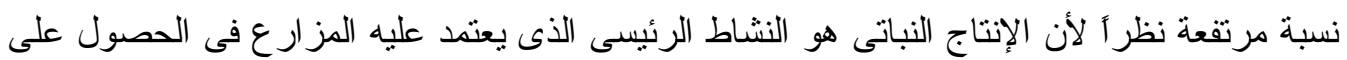

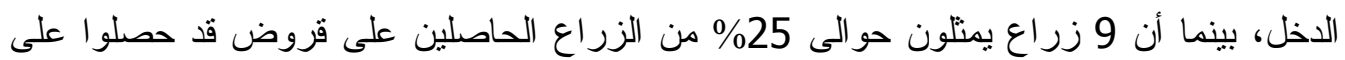

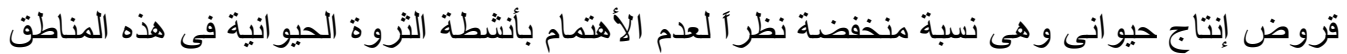

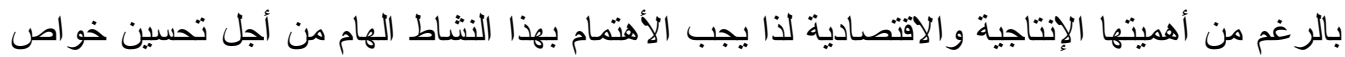

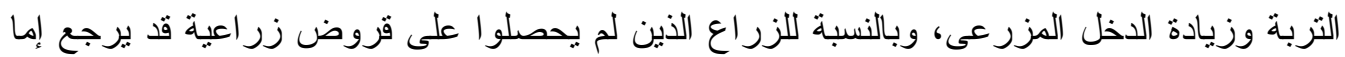

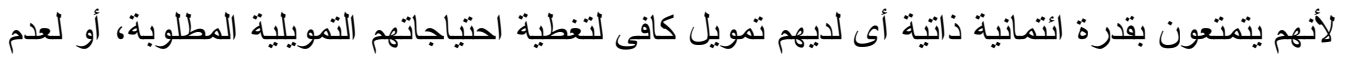
قدرتهم الائمانية فى الحصول على قروض من البنك نتيجة كثرة الاجر اءات الروتينية و التى تعد عائقاً

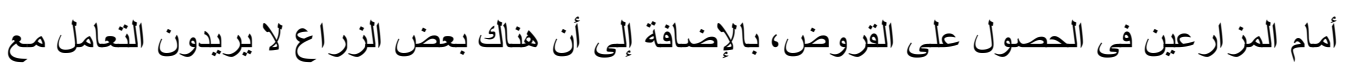

البنك بصفة عامة.

\begin{tabular}{|c|c|c|}
\hline$\%$ & 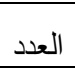 & الييــــــــــان \\
\hline 48.0 & 36 & حاصل على قروض زر اعية \\
\hline 52.0 & 39 & غير حاصل على قروض زر اعية \\
\hline 100.0 & 75 & الإجمالى \\
\hline
\end{tabular}

المصدر: جمعت وحسبث من بياتات الاستبيان بعينة البحث. 


\section{0- مدى كفاية قيمة القرض:}

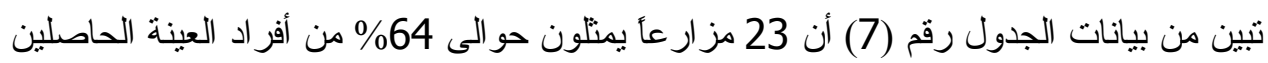

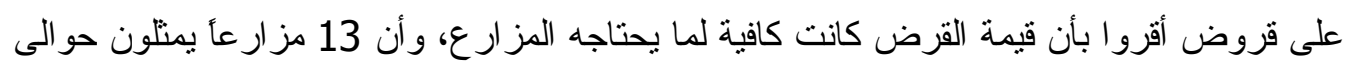

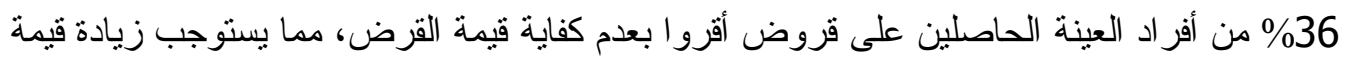

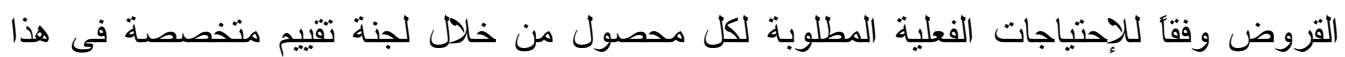
المجال.

جدول رقم (7): مدى كفاية قيمة القرض بالنسبة لأفر اد العينة.

\begin{tabular}{|c|c|c|}
\hline$\%$ & العدد & قيمة القرض \\
\hline 63.9 & 23 & كافى \\
\hline 36.1 & 13 & غير كافى \\
\hline 100.0 & 36 & الإجمالى \\
\hline
\end{tabular}

المصدر : جمعت وحسبت من بيانات الاستبيان بعينة البحث.

تناسب مواعيد صرف القرض:

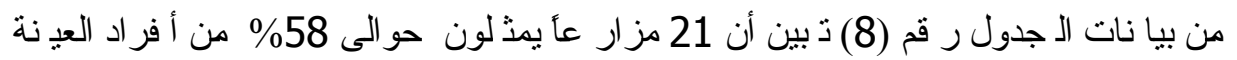

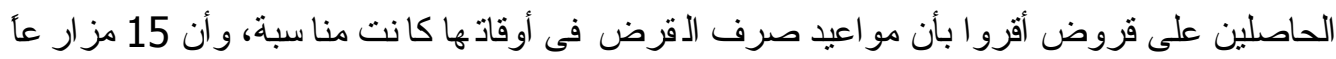

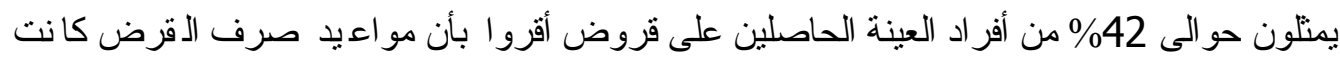

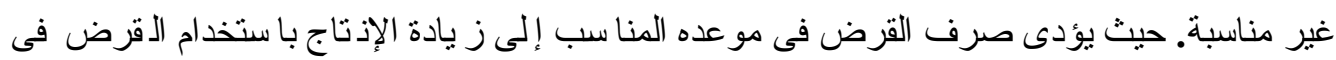

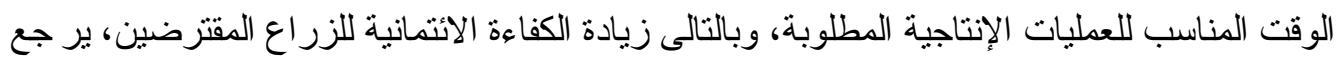

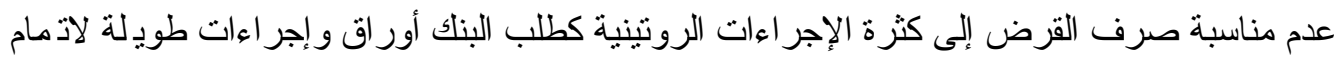

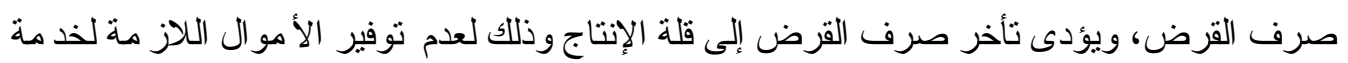
المحصول فى الوقت المناسب، مما يكون سبيأ فى انخفاض مستوى القدرة الائتمانية للمز ارعين . جدول رقم (8): مو اعيد صرف القرض في أوقاتها.

\begin{tabular}{|c|c|c|}
\hline$\%$ & العدد & ميعاد الصرف \\
\hline 58.3 & 21 & مناسب \\
\hline 41.7 & 15 & غبر مناسب \\
\hline 100.0 & 36 & الإجمالى \\
\hline
\end{tabular}

المصدر : جمعت وحسبت من بيانات الاستبيان بعينة البحث.

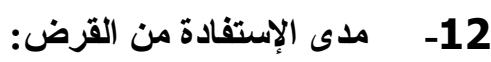

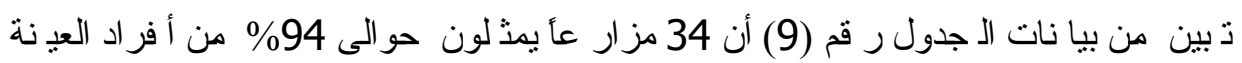

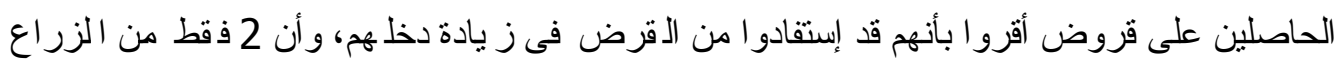

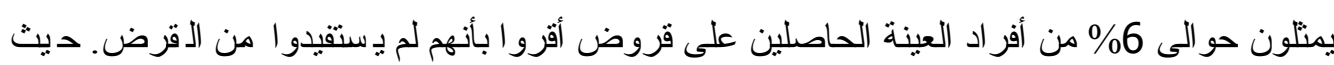

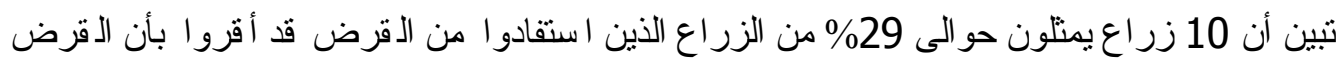

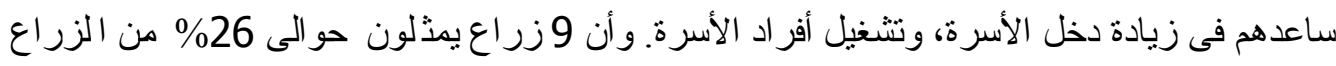

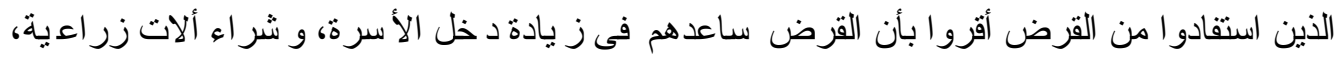

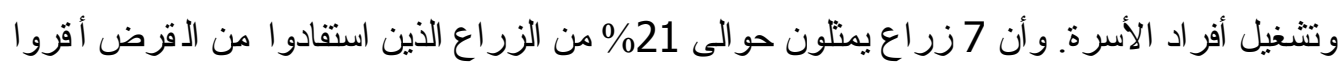

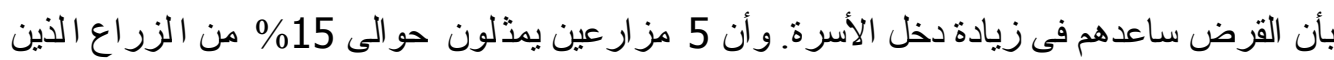

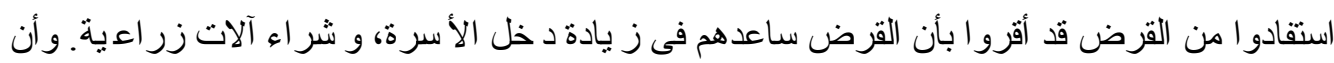


ثلاثة زر اع يمنلون حو الى 9\% من الزر اع الذين استفادو امن القرض أقرو أبأن القرض ساعدهم فى أقى

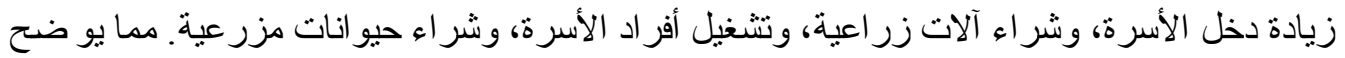

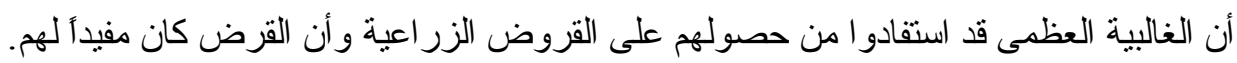

\begin{tabular}{|c|c|c|}
\hline \multicolumn{3}{|c|}{ جدول رقم (9): مدى الاستفادة من القرض فى زيادة دخلهم. } \\
\hline$\%$ & 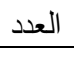 & مدى الأستفادة من القرض \\
\hline 94.4 & 34 & يستقيد \\
\hline 5.6 & 2 & لم بستقيد \\
\hline 100.0 & 36 & 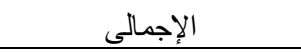 \\
\hline
\end{tabular}

المصدر: جمعت وحسبت من بيانات الاستبيان بعينة البحث.

13- مناسبة مواعيد سداد القرض:

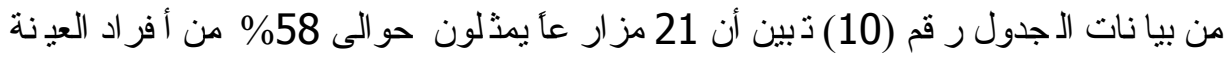

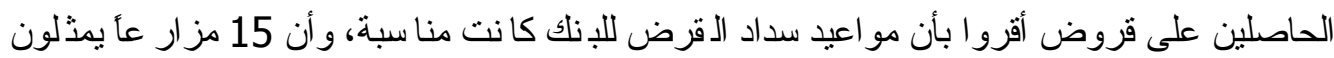

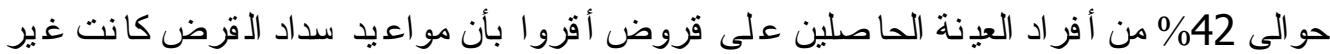

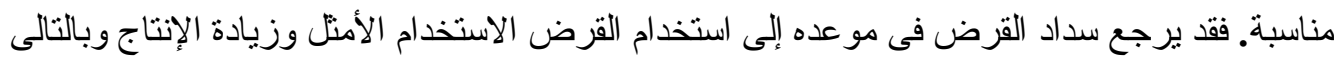

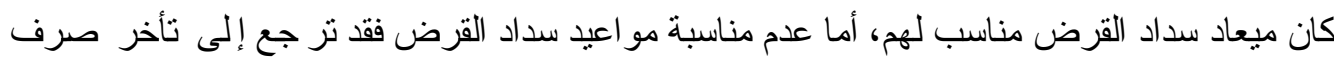

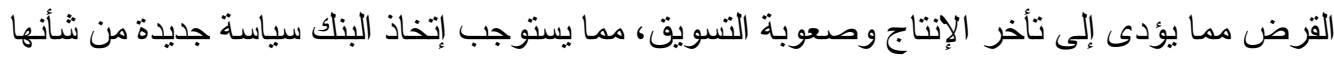

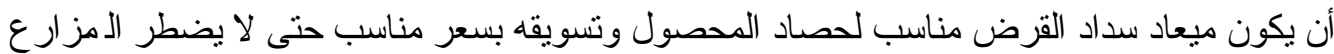

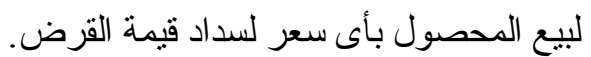

جدول رقم (10): مواعيد سداد القرض للبنك.

\begin{tabular}{|c|c|c|}
\hline$\%$ & العدد & ميعاد السداد \\
\hline 58.3 & 21 & مناسب \\
\hline 41.7 & 15 & غير مناسب \\
\hline 100.0 & 36 & الإجمالى \\
\hline
\end{tabular}

المصدر: جمعت وحسبت من بيانات الاستبيان بعينة البحث. 14- الإجراءات التى يتخذها البنك فى حالة عدم السداد:

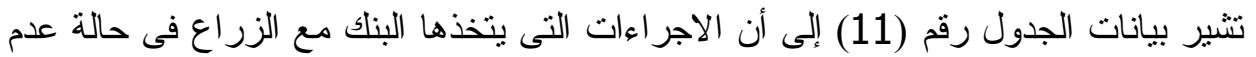

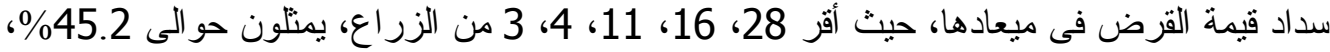

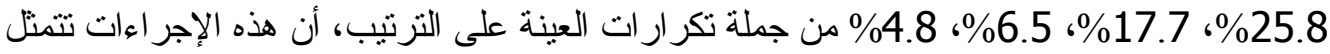

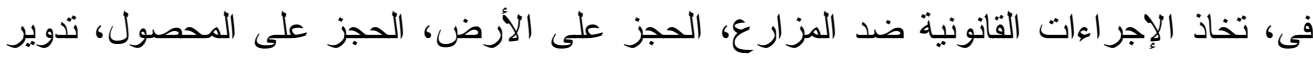
القرض، جدولة الديون وذلك على التزتيب. مما سبق ينبين أن هذه الإجر اءات التى يتخذها البنك ضد الإند

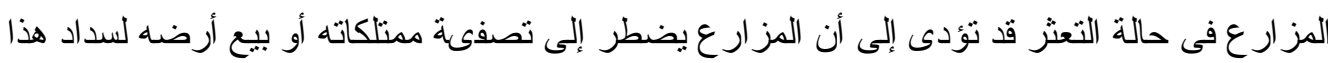

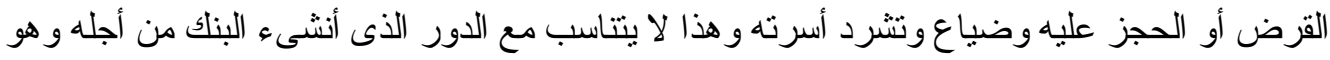

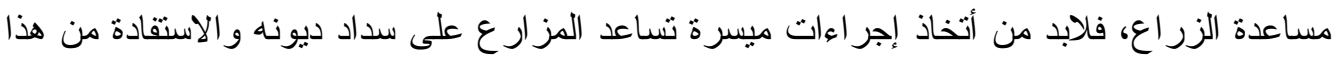




\begin{tabular}{|c|c|c|c|}
\hline \% من إجمالى & تكر ار من إجمالى العينة & ت ت تكر ارات العينة & الإجر اءات \\
\hline 37.3 & 45.2 & 28 & إتخاذ الإجر اءات القانونية ضد المزارع \\
\hline 21.3 & 25.8 & 16 & الحجز على الأرض \\
\hline 14.7 & 17.7 & 11 & الحجز على المحصول \\
\hline 5.3 & 6.5 & 4 & تدوير القرض \\
\hline 4.0 & 4.8 & 3 & جدولة الديون \\
\hline- & 100.0 & 62 & 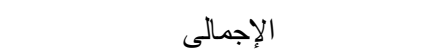 \\
\hline
\end{tabular}

المصدر: جمعت وحسبت من بيانات الاستبيان بعينة البحث.

15- التعامل مع البنك مستقبلاً:

تبين من بيانات الجدول رقم (12) أن 14 مزارعأ يمثلون حو الى 39\% من أفر اد العينة الحاصلين

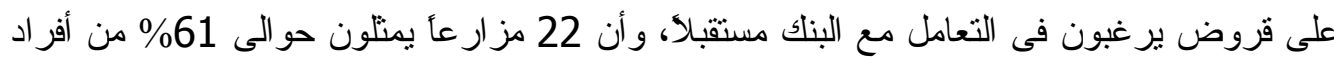

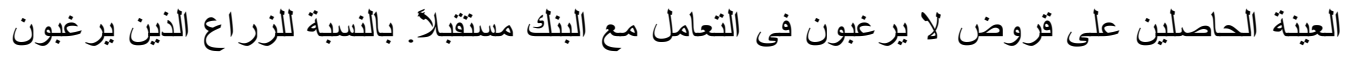

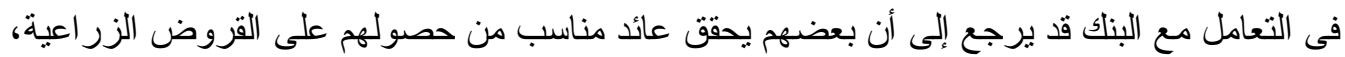

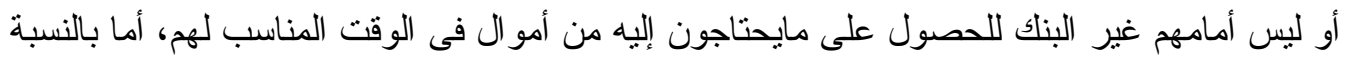

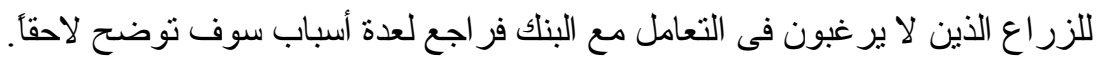
جدول رقم (12): رغبة الزراع فى التعامل مع البنك مستقبلاً.

\begin{tabular}{|c|c|c|}
\hline$\%$ & العدد & الر غبة فى التعامل \\
\hline 38.9 & 14 & برغب \\
\hline 61.1 & 22 & لا يرغب \\
\hline 100.0 & 36 & الإجمالى \\
\hline
\end{tabular}

المصدر: جمعت وحسبث من بيانات الاستبيان بعينة البحث.

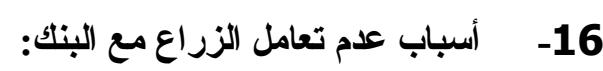

توضح بيانات الجدول رقم (13) التوزيع النسبى لأسباب عدم تعامل الزراع الع مع البنك أن 24

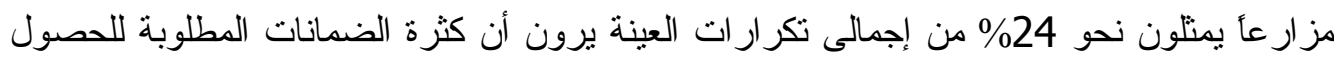

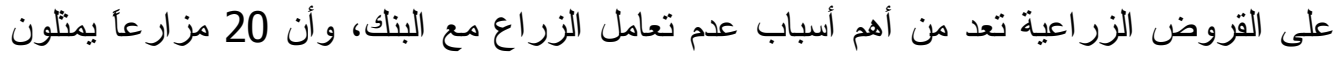

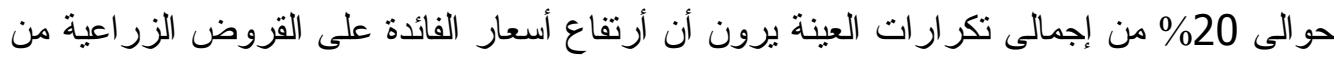

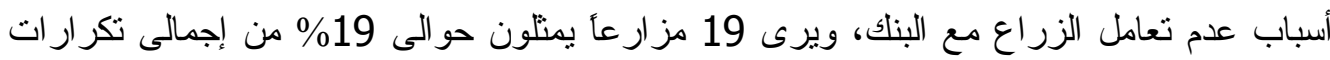

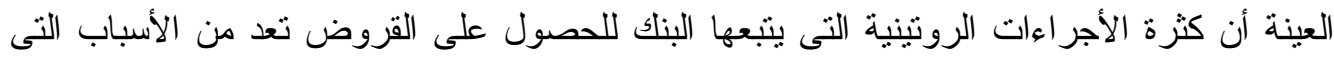

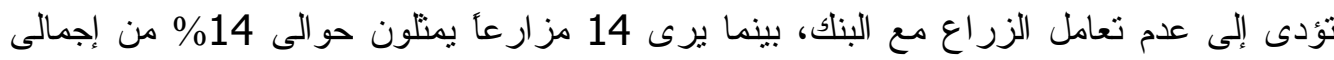

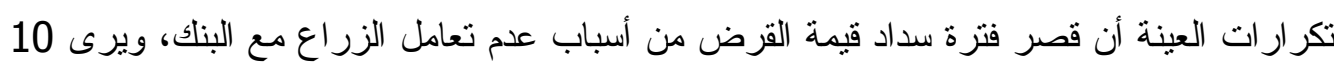

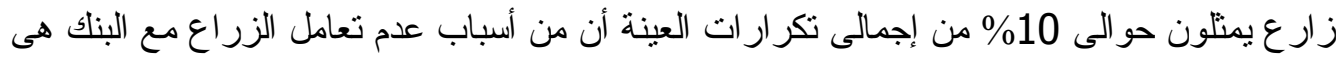

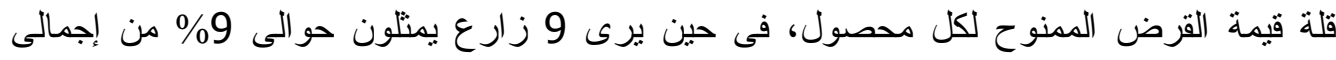

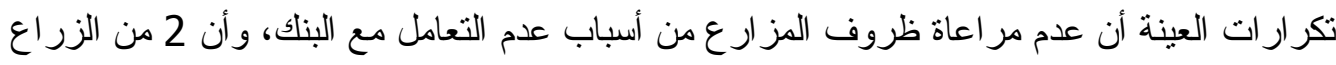

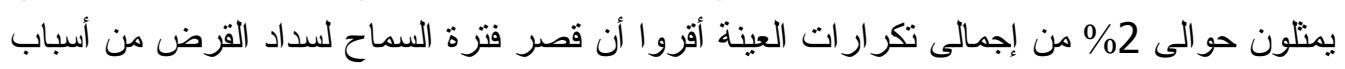


عدم تعامل الزراع مع البنك، كما أقر أيضاً 2 من الزراع يمثلون حوالى 2\% من إجمالى نكرارات

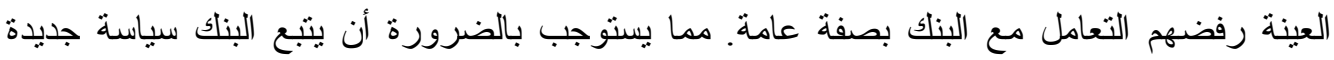

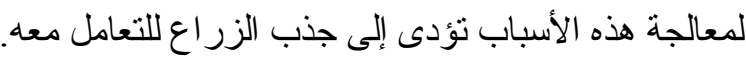

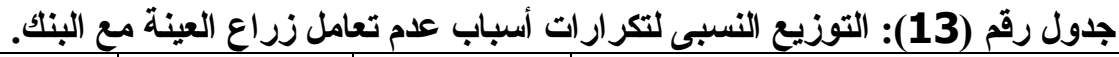

\begin{tabular}{|c|c|c|c|}
\hline 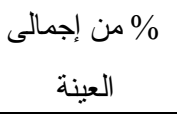 & 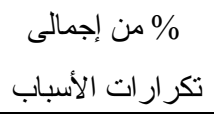 & 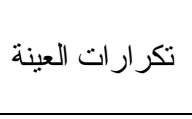 & الأسباب \\
\hline 32.0 & 24 & 24 & كثرة الضمانات المطلوبة للحصول على القروض \\
\hline 26.7 & 20 & 20 & أرتفاع أسعار الفائدة على القروض الزر اعية \\
\hline 25.3 & 19 & 19 & كثرة الأجر اءات الروتينية التى يتجعها البنك \\
\hline 18.7 & 14 & 14 & قصر فترة سداد قيمة القرض \\
\hline 13.3 & 10 & 10 & انخفاض قيمة القرض الممنوح لكل محصول \\
\hline 12.0 & 9 & 9 & عدم مر اعاة ظروف المز ارع \\
\hline 2.7 & 2 & 2 & قصر فترة السماح لسداد القرض \\
\hline 2.7 & 2 & 2 & برفض التعامل مع البناك \\
\hline- & 100 & 100 & 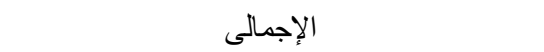 \\
\hline
\end{tabular}

المصدر: جمعت وحسبت من بيانات الاستبيان بعينة البحث. 17- المصدر البديل عن البنكك:

وينتين من بيانات الجدول رقم (14) أن 22، 6، 2 من الزر اع يمنلون حو الى 73.3\%، 20\%،

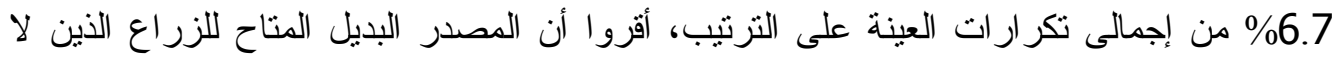

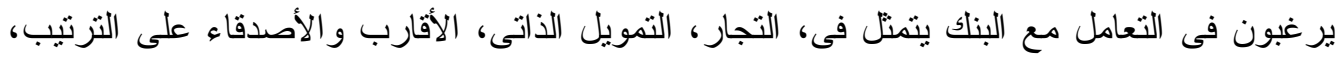

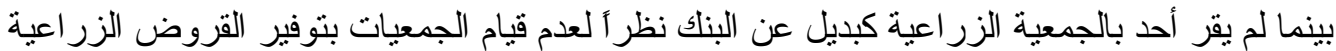
بالر غم من أن الجمعيات التعاونية الزر اعبة هى أقرب للمزارع عن أى مصدر آخر لذا فلابد من تفعيل

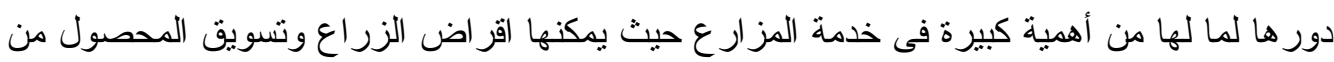

خلالها.

جدول رقم (14): التوزيع النسبى لتكرارات المصدر البديل عن البنك بعينة البحث.

\begin{tabular}{|c|c|c|c|}
\hline \% من إجمالى العينة & \% من إجمالى تكر ارات العينة & تكر ارات العينة & المصدر \\
\hline 29.3 & 73.3 & 22 & التجار \\
\hline 0 & 0 & 0 & الجمعية الزر اعية \\
\hline 8.0 & 20.0 & 6 & التمويل الذاتى \\
\hline 2.7 & 6.7 & 2 & الأقارب و الأصدقاء \\
\hline- & 100.0 & 30 & الإجمالى \\
\hline
\end{tabular}


أسباب تعامل الزراع مع المصدر البديل عن البنك:

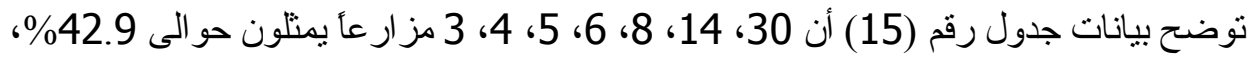

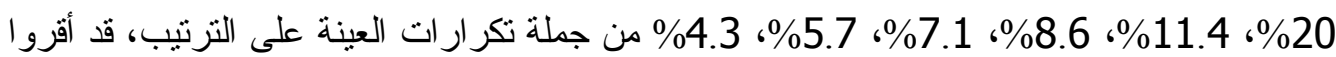
أن أسباب تعامل الزراع مع المصدر البديل عن البنك تمنلت فى، سهولة الحصول على ما يحتاج إليه

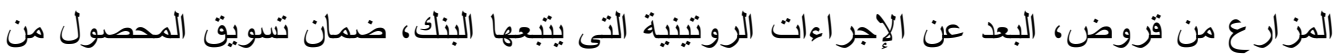

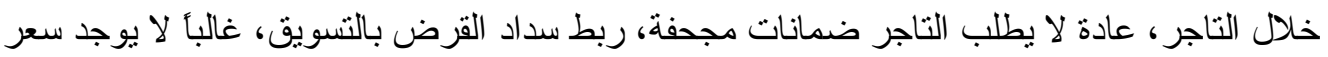
فائدة على القروض، الاعتماد على التمولى لاديل الذاتى.

جدول رقم (15): التوزيع النسبى لتكر ارات أسباب تعامل الزراع مع المصدر البديل عن البنك.

\begin{tabular}{|c|c|c|c|}
\hline \% من إجمالى العينة & تكر ارات الأسباب & ت ت تكر ارات العينة & الأسباب \\
\hline 40 & 42.9 & 30 & سهولة الحصول على ما يحتاج إليه الدز ارع من قروض \\
\hline 18.7 & 20.0 & 14 & بعيدأ عن الإجر اءات الروتينية التى يتبعها البنك \\
\hline 10.7 & 11.4 & 8 & ضمان تسويق المحصول من خلال التاجر \\
\hline 8 & 8.6 & 6 & عادة لا يطلب التاجر ضمانات \\
\hline 6.7 & 7.1 & 5 & ربط سداد القرض بالتسويق \\
\hline 5.3 & 5.7 & 4 & غالباً لا يوجد سعر فائدة على القروض \\
\hline 4.0 & 4.3 & 3 & الاعتماد على التمويل الذاتى \\
\hline- & 100.0 & 70 & الإجمالى \\
\hline
\end{tabular}

المصدر: جمعت وحسبت من بيانات الاستبيان بعينة البحث.

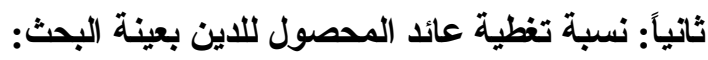

لار اسة الجدراة الائتمانية لمزارعى العينة والوقوف على لئى مدى قدرتهم على تحقيق عائد وزيادة

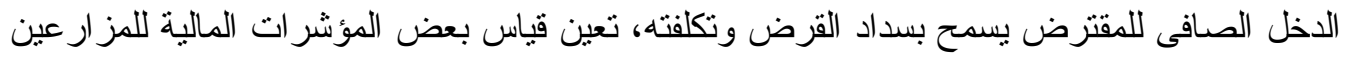

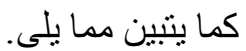

هذه النسبة نقيس عدد مر ات تغطية إجمالى عائد المحصول للاين، ويمكن قياسها بالمعادلة التالية. نسبة تغطية عائد المحصول للدين = إجمالى العائد / إجمالى الدين.

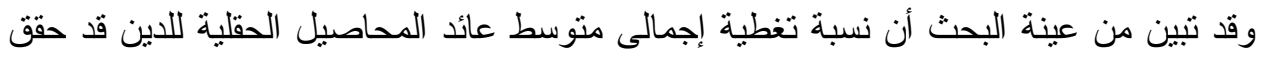

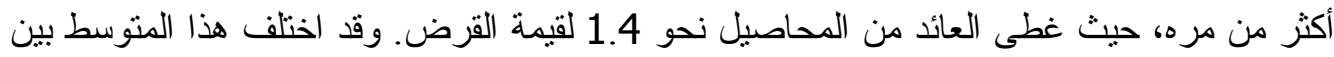

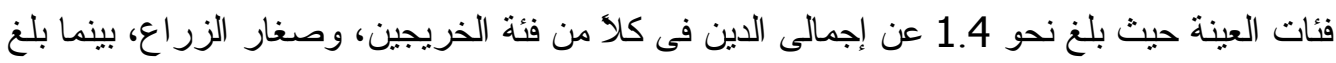

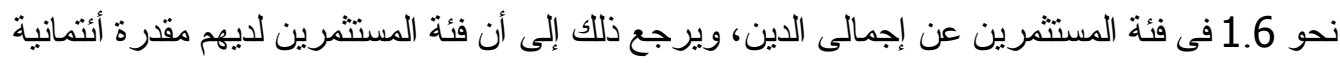

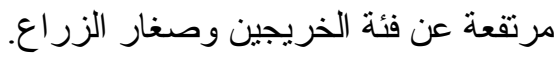
وتبين أن نسبة تغطية إجمالى متوسط عائد محاصيل الخضر للاين فقد حقق تغطية للقرض أكثر

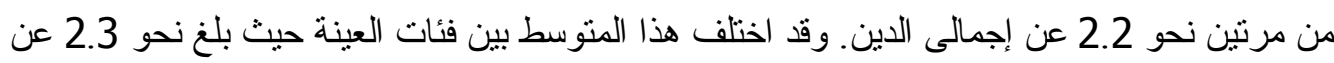
إجمالى الدين فى فئة الخريجين، وبلغ نحو 1.9 عن إجمالى الدين فى فئة صغار الزر اع، بينما بلغ لئن

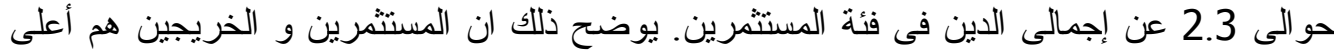
فئتان وذللك لأنهم يتمتعون بالمقدرة الائتمانية و الخبرة . 
كما تبين ان نسبة تغطية العو ائد لمتوسط إجمالى القروض لمحاصيل الفاكهة فقد حقق ثلاث مر ات عن إجمالى الدين. وقد اختلف هذا المتوسط بين فئات العينة، فقد حقق أكثر من ثلاث مر ات، نحو 3.3 مرة عن إجمالى الدين فى فئة صغار الزر اع، بينما بلغ 4.5 مرة عن إجمالى الدين فى فئة المستثمرين. أ: نسبة تغطية العو ائد لقروض محاصيل عينة البحث: 1- تغطية العائد للاين للمحاصيل الحقلية:

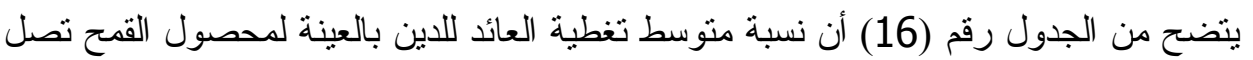

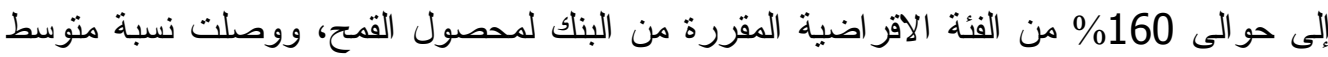
تغطية العائد للدين بالعينة لمحصول الذرة إلى حو الى 120\% من الفئة الاقراضية المقررة من البنك

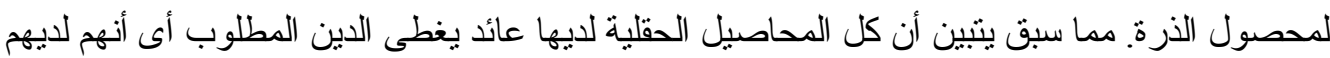

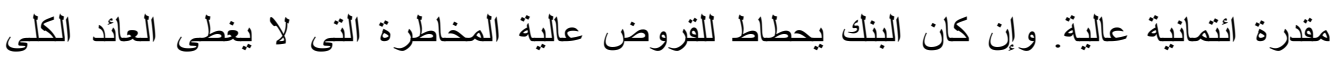

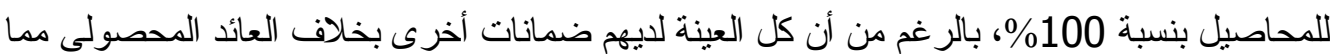
يجعل لايهم القدرة الائتمانية التى تفوق 100\% من العائد المحصولى لديهم بل يوجد بعض المحاصيل التى يمكن أن تغطى الدين البنكى من صافى العائد المحصولى لفئ. 2- تغطية العائد للاين بمحاصيل الخضر :

كما تبين من بيانات الجدول رقم (16)، أن نسبة متوسط تغطية العائد للدين بالعينة لمحصول الطماطم قد تصل إلى حو الى 290\% من الفئة الاقر اضية المقررة من البنك لمحصول الطماطم، كما

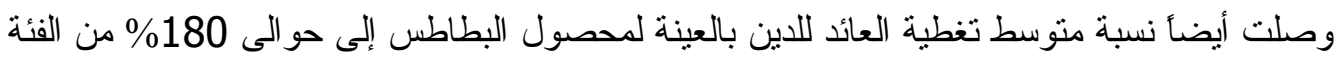

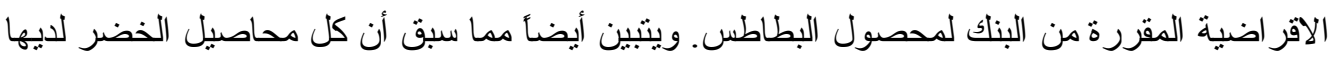
صافى عائد يغطى الدين المطلوب أى أنهم لايهز قدرة ائتمانية عالية. جدول رقم (16): متوسط تغطية العائد للاين بمحاصيل عينة البحث علئ الئه

\begin{tabular}{|c|c|c|c|c|c|}
\hline تغطية صافى العائد & للاين للمط العائدة & للمنوسط الدين & صنافى العائد & إجمالى العائد & نوع المحصول \\
\hline 0.59 & 1.6 & 9413 & 5563 & 14887 & القمح \\
\hline 0.36 & 1.2 & 9737 & 3527 & 11830 & الذرة الثشامية \\
\hline 0.475 & 1.4 & 9575 & 4545 & 13358.5 & متوسط المحاصيل \\
\hline 1.12 & 2.9 & 18437 & 20645 & 53736 & الطماطم \\
\hline 0.36 & 1.8 & 25060 & 15703 & 43977 & البطاطس \\
\hline 0.88 & 2.3 & 21748.5 & 18174 & 48865.5 & متوسط محاصيل الخضر \\
\hline 0.82 & 4.9 & 190447 & 155333 & 942000 & الموز \\
\hline 1.22 & 2.7 & 18437 & 22500 & 50000 & الليمون - م الليمن \\
\hline 1.02 & 3.8 & 104442 & 88916.5 & 496000 & متوسط محاصيل الفاكهة \\
\hline
\end{tabular}

المصدر : جمعت وحسبت من بيانات العينة.

3ـ تفطية العائد للاين بمحاصيل الفاكهة:

وينبين من الجدول رقم (16) السابق، أن نسبة متوسط تغطية العائد للاين بالعينة لمحصول الموز

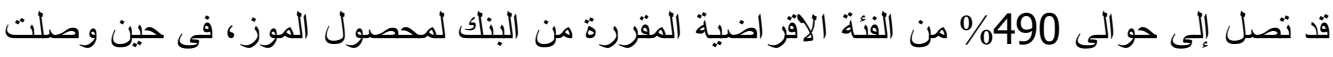
نسبة منوسط تغطية العائد للدين بالعينة لمحصول الليمون إلى حوالى 270\% من الفئة الاقراضية المقررة من البنك لمحصول الليمون. كما يتبين أيضأ مما سبق أن كل محاصيل الفاكهة لديها صافى عائد يغطى الدين المطلوب أى أنهم لديهم مقدرة ائتمانية عالية. 
ثالثاً: أثر تظطية الاتتمان للتكاليف على إنتاجية المحاصيل:

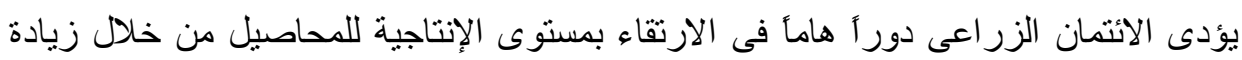

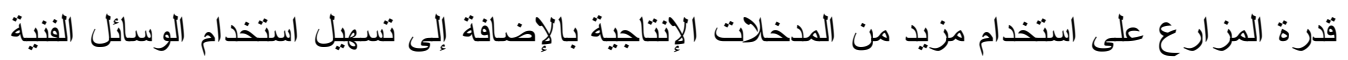

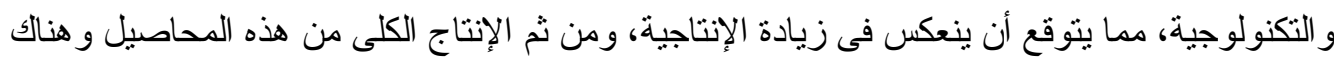

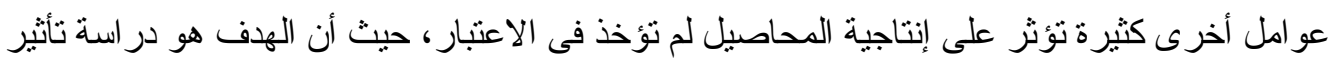

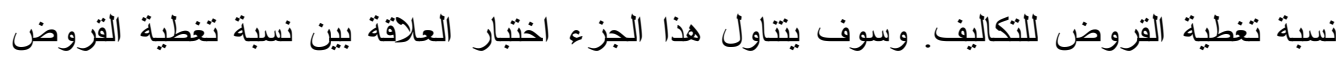

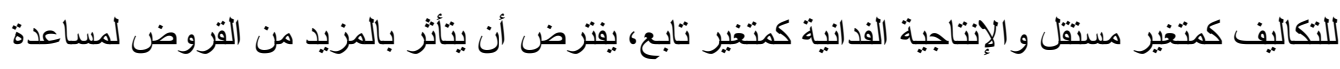

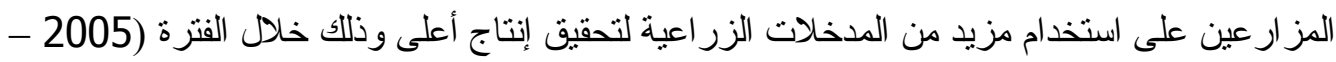
2016) وللمحاصيل موضع البحث.

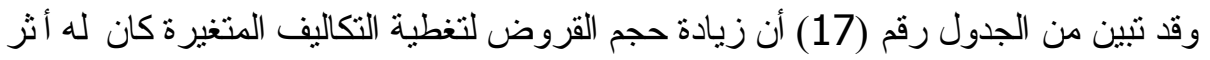

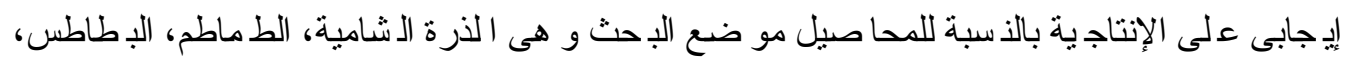

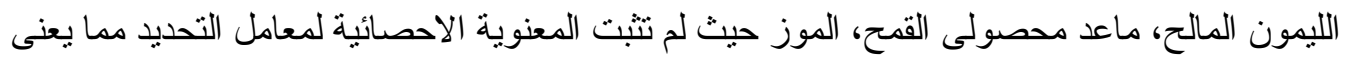

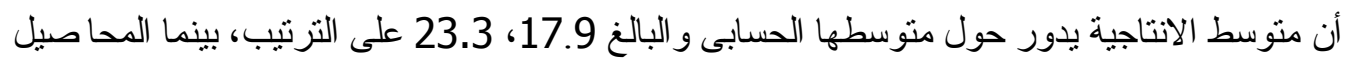

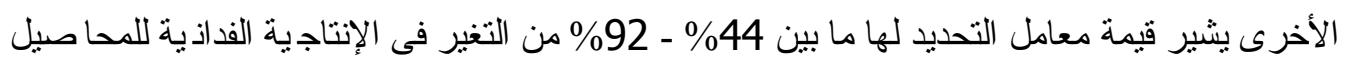

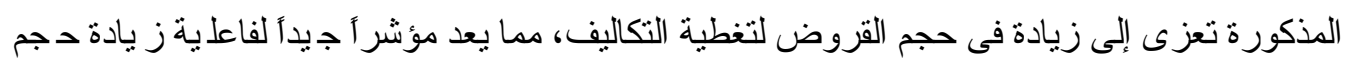

القروض فى تشجيع استخدام التكنولوجيا. رابعاً: العلاقة بين الاتثمان وصافى العائد الفدانى:

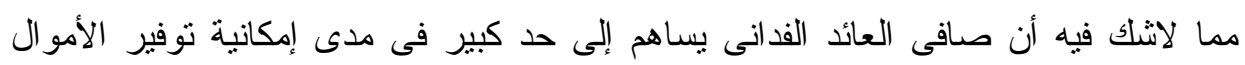

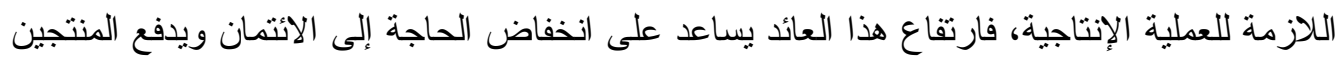

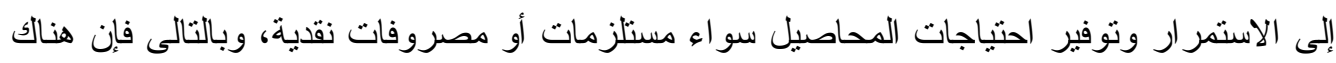
علاقة بين الائتمان الفدانى وصافى العائد الفدانى تعكس حقيقة دور السياتسات العات الأتنمانية فى الاهنمام بتتجيع زر اعة المحاصيل الزر اعية الأساسية. جدول (17): العلاقات الدالية بين متوسط الإتتاجية ونسبة تغطية القروض الفدة الفية النية للتكاليف المتغيرة الفدانية لمحاصيل العينة خلال الفترة (2005- 2016)

\begin{tabular}{|c|c|c|c|c|}
\hline ف & 2 & المتوسط & الــــــــالة & المحصول \\
\hline 0.136 & 0.13 & 17.9 & 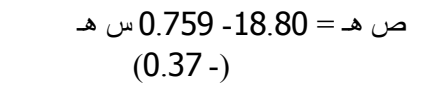 & القمح \\
\hline$* 7.7$ & 0.44 & 22.14 & $\begin{array}{l}\text { ص هـ = } 2601.17 \text { س سـ } 53.83 \text { هـ } 2.78) \\
\text { هـ }\end{array}$ & الذرة الثامية \\
\hline *9.37 & 0.51 & 11.61 & $\begin{array}{l}\text { ص هـ = } 5714.7+3925.23 \text { س هـ } \\
\text { هـ } 3.24)\end{array}$ & البطاطس \\
\hline$* 9.4$ & 0.49 & 15 & 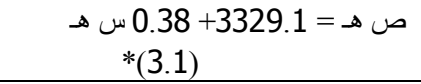 & الطماطم \\
\hline$* * 121.84$ & 0.92 & 10.13 & 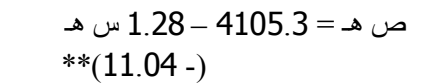 & الليمون المالح \\
\hline 1.56 & 0.14 & 23.26 & ص هـ = 43055.2 - 57559 س هـ (1.25 ) & الموز الوليم \\
\hline
\end{tabular}

* * مغوى عند مستوى معنوية 0.01 * معنوى عند مستوى معنوية 0.05 ميث: ص هـ = متوسط الإتاجية الفدانية.

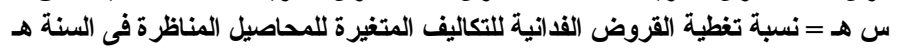
12

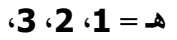

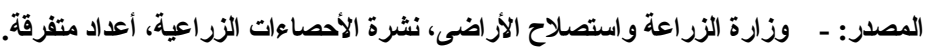

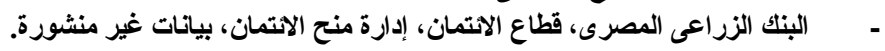


وقد تبين أن محاصيل العينة تختلف فيما بينها من حيث صافى العائد الفدانى اختلافأ كبير آ حيث بلغ هذا العائد نحو 3165.9، 2353.9، 4627.7، 13167، لمحاصيل القمح و الذرة الثامية و البطاطس و الطماطم و الليمون المالح و الموز الوليم على الترنيب كمتوسط للفترة من (2005 - 2016) وبالتالى فإن هذا الاختلاف فى صافى العائد سوف يؤثنر بشكل كبير على إنتاجية تلك المحاصيل ومن ثم فإن التسهيلات الاثتمانية سوف تؤدى دور أ كبير أ فى الحد من فئن

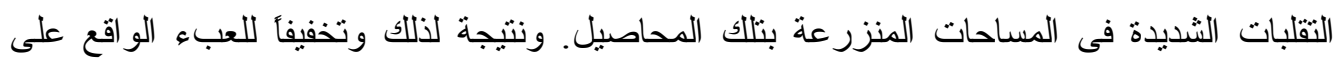

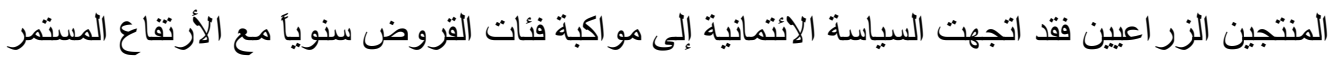

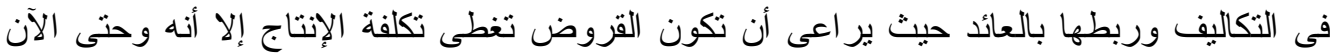

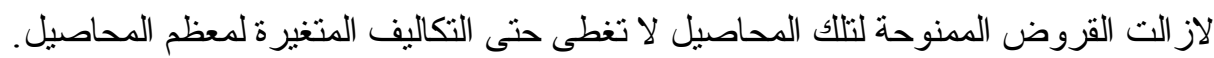

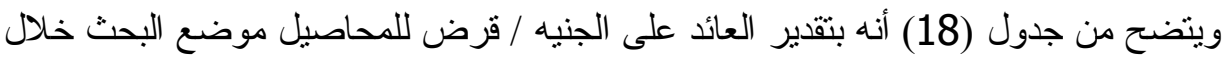

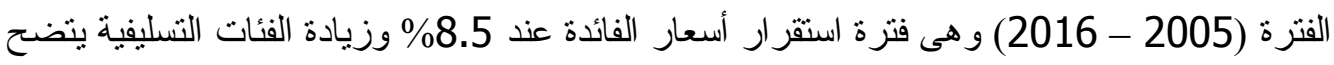
أن العائد على الجنيه كان مختلفاً بسبب التباين فى صافى العائد وكان أكثر ما يمكن بالنسبة لمحصول الموز حيث بلغ نحو 5.5 جنيه / قرض، يليه محصول الطماطم بعائد قدر بنحو 3.1 جنيه، ثم محصول

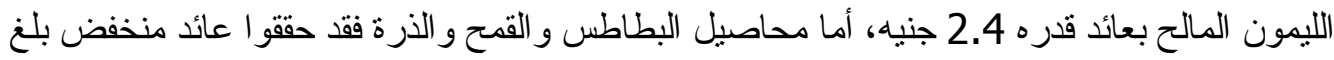
نحو 1.4، 1.4، 1.3 جنيه على النزتيب.

جدول رقم (18): متوسط العائد على الجنيه من القروض الزر اعية المقدمة من البنك الزراعى المصرى لمحاصيل العينة خلال الفترة (2005 - 2016).

\begin{tabular}{|c|c|c|c|c|c|c|}
\hline موز وليم & ليمون مالح & طماطم & بطاطس & ذرة شامية & قمح & الشيان. \\
\hline 14863 & 5235 & $1162-$ & 1515 & $126.7-$ & $419.3-$ & لها قـروض تكلفة عناصر لم يقام \\
\hline 1593.8 & 3041.7 & 1593.8 & 1377.8 & 1270.6 & 1593.8 & 2- القيمة الإيجارية \\
\hline 1593.8 & 3041.7 & 1593.8 & 1377.8 & 1270.6 & 1593.8 & 3ـ عائد المز ارع (2) \\
\hline 18050.8 & 11318.8 & 2025.4 & 4270.6 & 2414.5 & 2696.3 & 4- الجملة \\
\hline 8387.9 & 5290.1 & 5130.9 & 7424.8 & 2977.8 & 3103.9 & قروض تكلفة عناصر قدم لها \\
\hline 64098.7 & 23857.5 & 17959.4 & 14473.8 & 6286 & 7174.8 & 6ـ الإير اد الكلى \\
\hline 46048.7 & 12538.8 & 15934 & 10203.3 & 3871.5 & 4478.5 & 7ـ العمنوحة العدى على القروض \\
\hline 5.49 & 2.37 & 3.11 & 1.37 & 1.30 & 1.44 & 8ـ العائد على جنيه / \\
\hline
\end{tabular}

المصدر : - وزارة الزراعة واستصلاح الأراضى، نشرة الاحصاءات الزراعية، أعداد متفرقة.

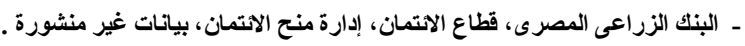

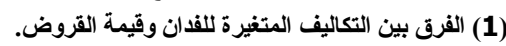

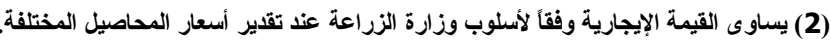
(3) تمثل الاتتمان الفدانى متضمناً الفائدة. 
مما سبق نستتتج أنه بالرغم من ارتفاع الفئات التسليفية لمختلف المحاصيل لتغطى نسبة كبيرة من

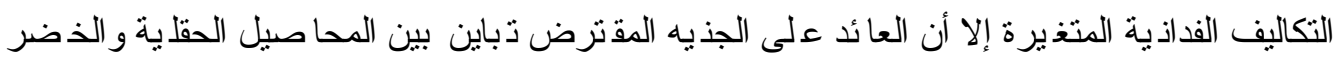

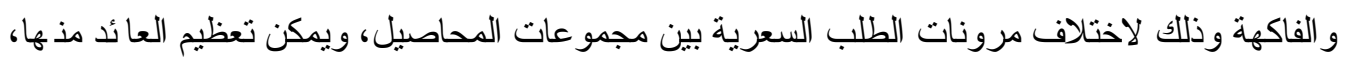
و العمل على استقرار دخول المز ارعين من خلال تطوير سيا سة التسويق الزر اعى عن طر يق د خول لاتل

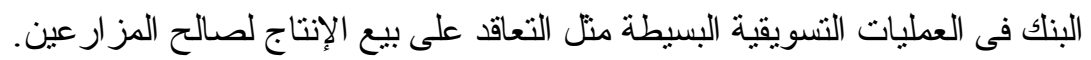
خامساً: أهم المشاكل التى تواجه أفراد عينة البحث، وكيفية التقلب عليها: أ: أهم المشاكل التى تواجه الزراعيأ بعينة البحث:

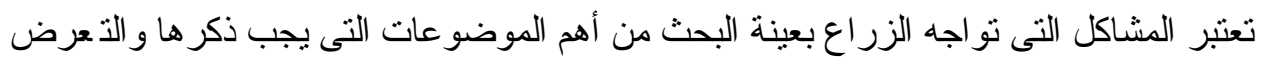

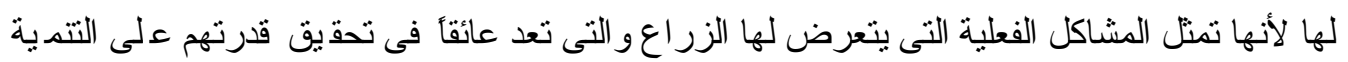
الزر اعية فى تلك المناطق الجديدة.

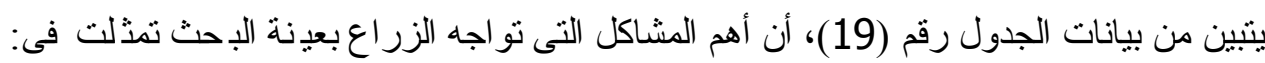

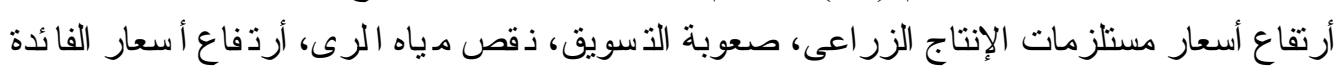

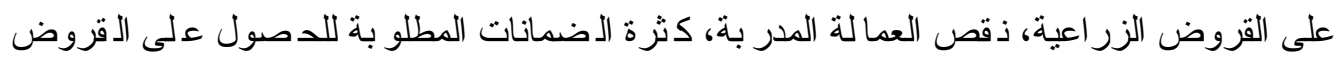

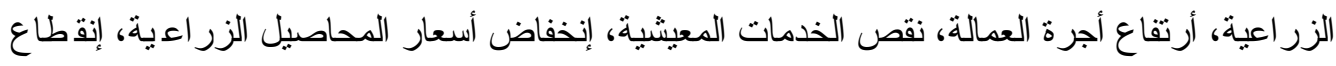

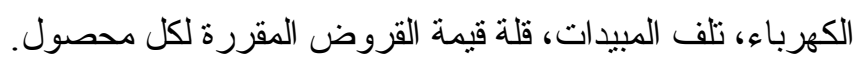

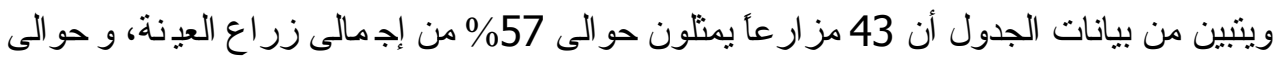

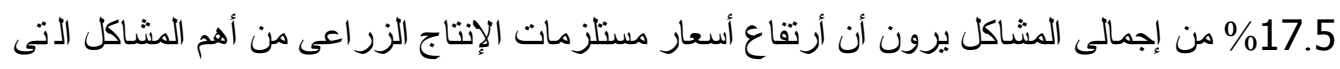

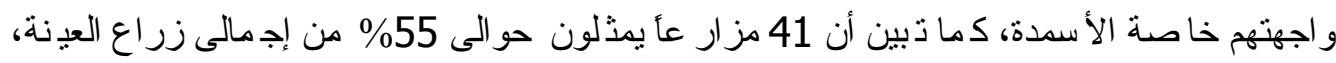

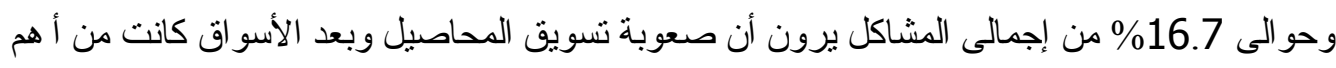

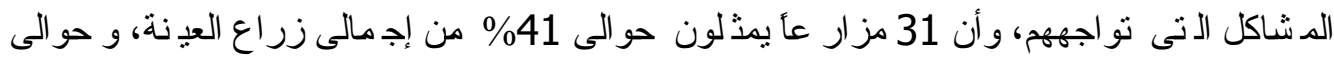

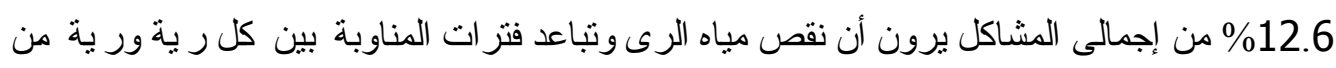

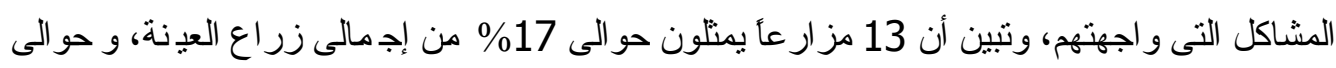

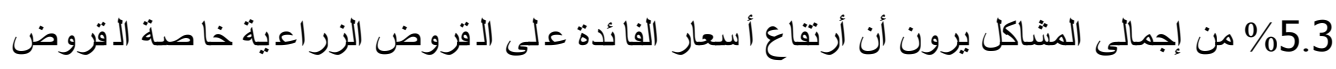

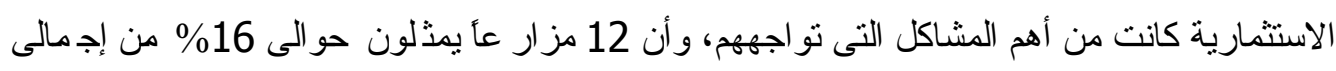

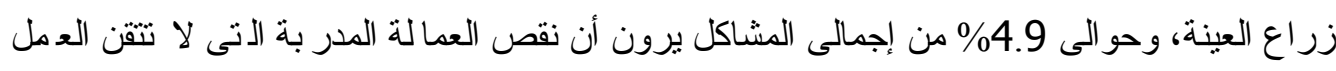

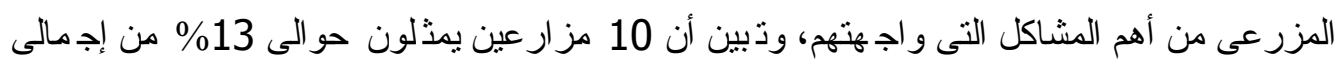

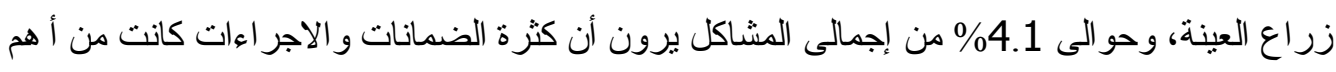

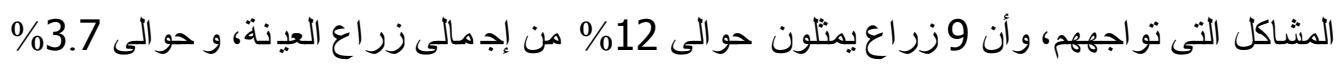

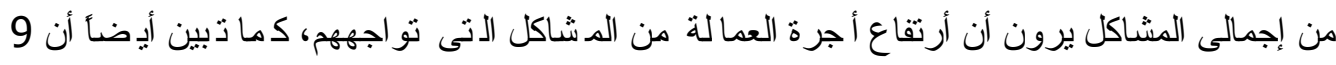

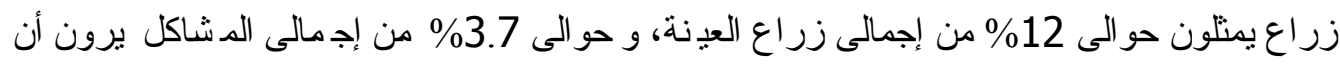

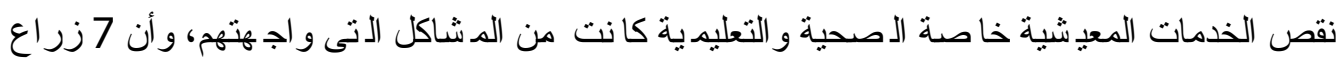

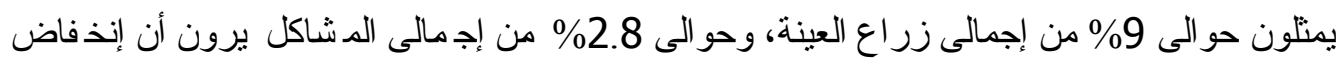

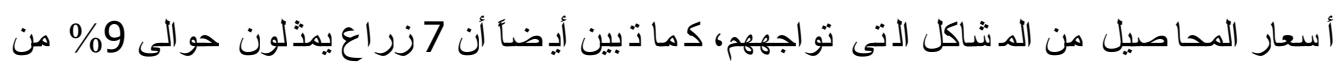

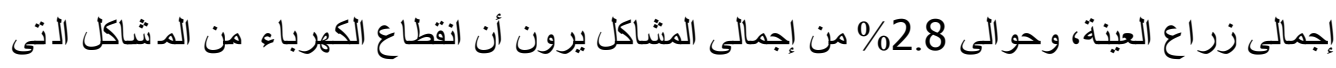

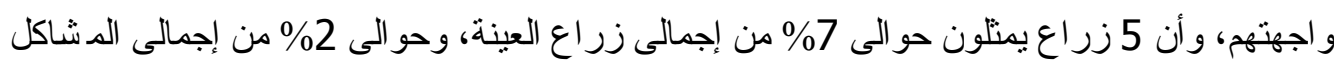

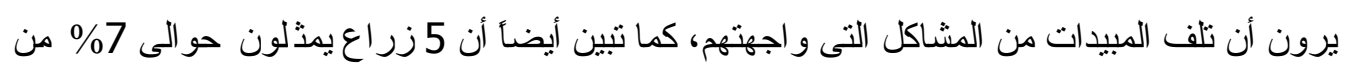


إجمالى زراع العينة، وحو الى 2\% من إجمالى المشاكل برون أن قلة قي مة القروض على المحاصيل الزر اعية من المشاكل النى و اجهتهم.

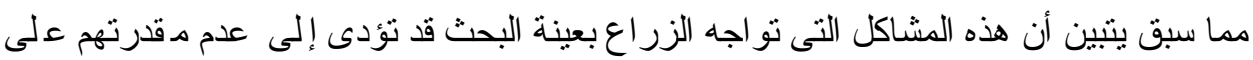

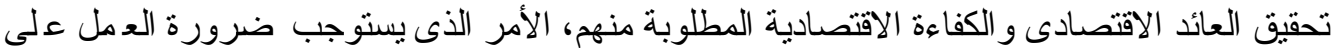
حل هذه المشاكل من قبل الجهات المعنية. جدول رقم (19): التوزيع النسبى لتكرارات أهم المشاكل التى واجهة زراع العينة.

\begin{tabular}{|c|c|c|c|}
\hline \% من إجمالى العينة & \% من إجمالى & جملة تكر ارات & المشـــــــــــاكل \\
\hline 57 & 22.4 & 43 & أرتفاع أسعار مستلزمات الإنتاج الزر اعى \\
\hline 55 & 21.4 & 41 & صعوبة تسويق الدحاصيل الزر اعية \\
\hline 41 & 16.1 & 31 & نقص مياه الرى \\
\hline 17 & 6.8 & 13 & أرتفاع أسعار الفائدة على القروض الزر اعية \\
\hline 16 & 6.3 & 12 & نقص العمالة المدربة \\
\hline 13 & 5.2 & 10 & كثرة الضمانات المطلوبة للقرض \\
\hline 12 & 4.7 & 9 & أرتفاع أجرة العمالة الزر اعية \\
\hline 12 & 4.7 & 9 & نقص الخدمات المعيشية \\
\hline 9 & 3.6 & 7 & إنخفاض أسعار المحاصيل الزر اعية \\
\hline 9 & 3.6 & 7 & إنقطاع الكهرباء \\
\hline 7 & 2.6 & 5 & تلف المبيدات الزر اعية \\
\hline 7 & 2.6 & 5 & قلة قيمة القروض المقررة على المحاصيل الزر اعية \\
\hline- & 100.0 & 192 & 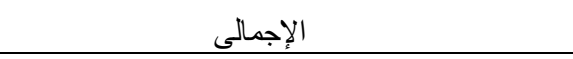 \\
\hline
\end{tabular}

المصدر: جمعت وحسبت من بيانات الاستبيان بعينة البحث. ب: مقترحات حل المشاكل التى تواجه الزراع بعينة البحث: تعد مقترحات الزر اع لحل المشاكل التى تو اجههم على جانب كبير من الأهمية و لا بمكن إغفال ها

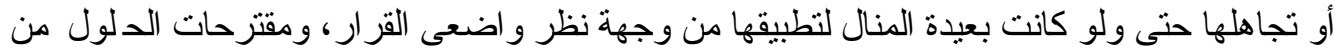

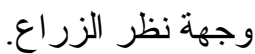

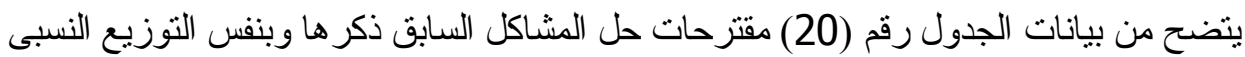
لتكر ار ات أهم المشاكل على الترتيب التى تو اجه الزر اع بعينة البحث من وجهة ذظر هم، و التى تمدّلت

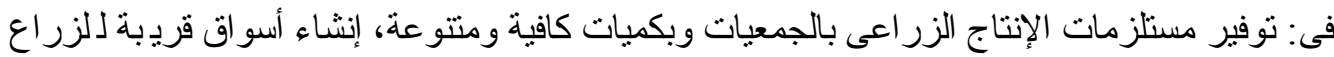
لتقليل تكاليف النقل وسهولة التسويق، زيادة فترة وحصة المناوبة من مياه الرى، تخفيف أسعار الفائدة

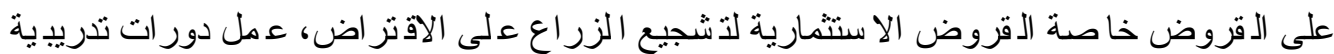

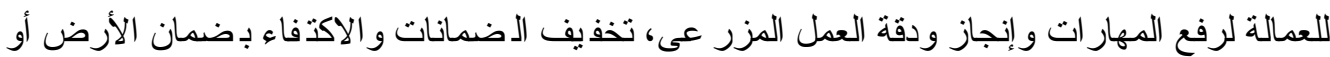
المحصول، توفير وسائل نقل مناسبة و اقامة مريحة لجذب العمالة، توفير كافة الخدمات المعيشية خاصية

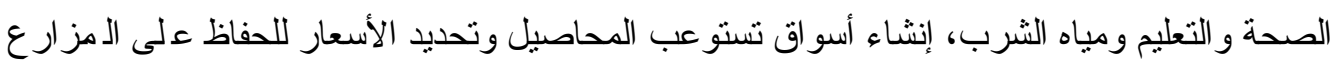
من استغلال التجار ، عمل صيانة دورية لشبكة الكهرباء وزيادة المحولات، توفير المبيدات بالجمعيات لضمان سلامنها، منح قيمة القروض الفعلية اللازمة لكل محصول. 


\begin{tabular}{|c|c|c|c|}
\hline 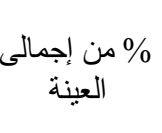 & تكر ار من إجمالى & تكرار اتلة & المقترحات \\
\hline 57 & 22.4 & 43 & توفير مستلزمات الإنتاج الزر اعى بالجمعيات وبكميات كافية \\
\hline 55 & 21.4 & 41 & إنثاء أسو اق قريبة للزر اع لنقليل تكاليف النقل وسهولة التسويق \\
\hline 41 & 16.1 & 31 & زيادة فترة وحصة المناوبة من مياه الرى \\
\hline 17 & 6.8 & 13 & 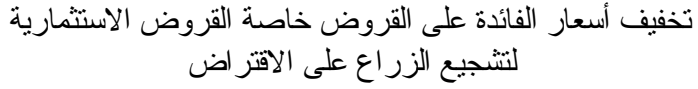 \\
\hline 16 & 6.3 & 12 & عمل دور ات تدرييية للعمالة لرفع المهار ات و إنجاز ودقة العمل \\
\hline 13 & 5.2 & 10 & تخفيف الضمانات و الاكتفاء بضمان الأرض أو المحصول \\
\hline 12 & 4.7 & 9 & توفير وسائل نقل مناسبة و اقامة مريحة لجذب العمالة \\
\hline 12 & 4.7 & 9 & توفير كافة الخدمات المعيشية خاصة الصحة و التعليم ومياه \\
\hline 9 & 3.6 & 7 & إنثاء أسو اق تستو عب المحاصيل وتحديد الأسعار للحفاظ على المن التخار \\
\hline 9 & 3.6 & 7 & عمل صيانة دورية لشبكة الكهرباء وزيادة المحو لات \\
\hline 7 & 2.6 & 5 & توفير المبيدات بالجمعيات لضمان سلامتها \\
\hline 7 & 2.6 & 5 & منح قيمة القروض الفعلية اللازمة لكل محصول \\
\hline- & 100.0 & 192 & 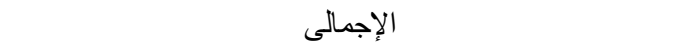 \\
\hline
\end{tabular}

المصدر: جمعت وحسبت من بياتات الاستبيان بعينة البحث.

\section{الملخص و التوصيات}

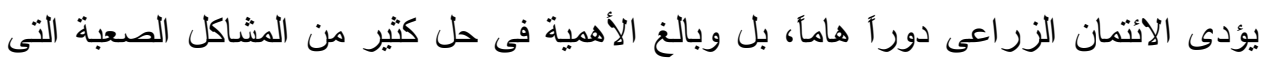

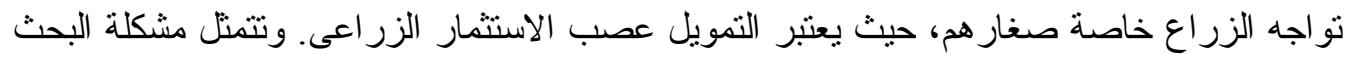

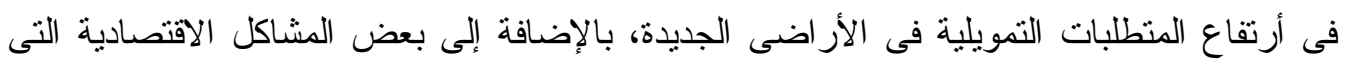

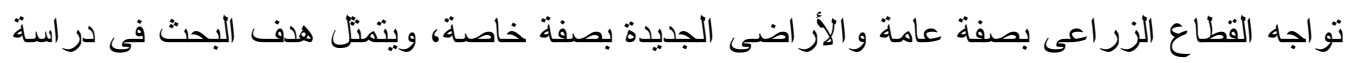
المقدرة الائتمانية لعينة من المز ارعين فى الأر اضى الجديدة، و الوقوف على مدى قدرتهم على تحقيق

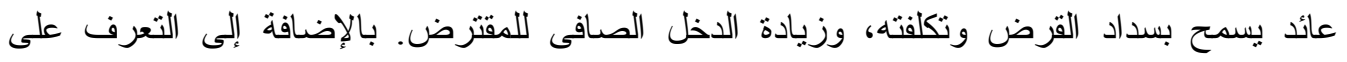

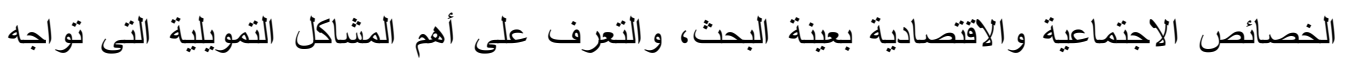
مز ار عى الأر اضى الجديدة، وكيفية التغلب عليها.

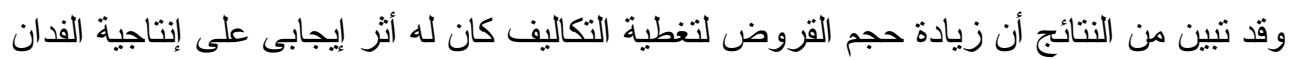

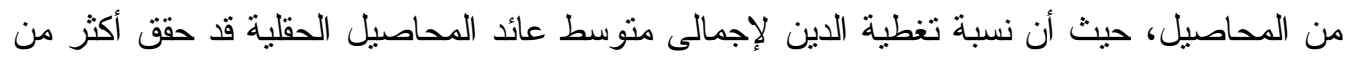

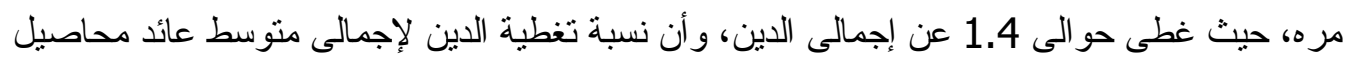
الخضر فقد حقق أكثر من مرتين أى حوالى 2.2 عن إجمالى الدين، أما بالنسبة لنسبة تغطية الدين

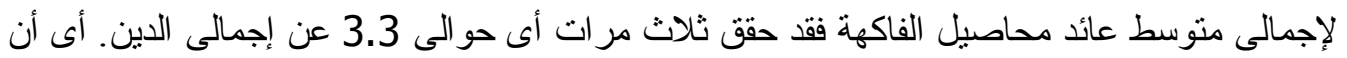

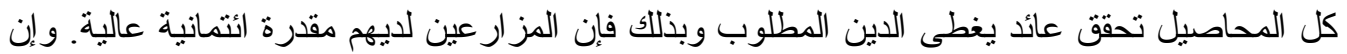


كان البنك يحطاط للقروض التى يمنحها عالية المخاطرة مما يجعله لا يغطى العائد الكلى للمحاصيل

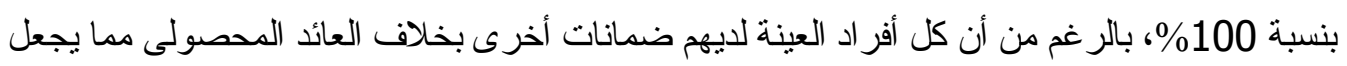
لديهم القدرة الائمانية النى تقوق 100\% بالرغن من العائد المحصولى لديهم بل يوجد بعض الدحاصيل التى لنى يمكن لمز ار عيها أن تغطى الدين البنكى من صافى العائد المحصولى لقئ. التوصيات

فى ضوء النتائج التى تم التوصل إليها فإن البحث يوصى بما يلى:

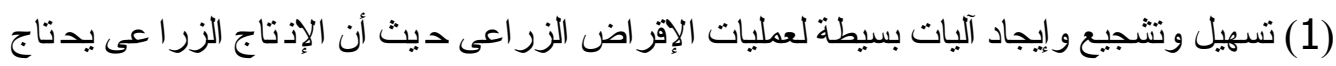
إلى هذه القروض خاصة فى الأر اضى الجديدة.

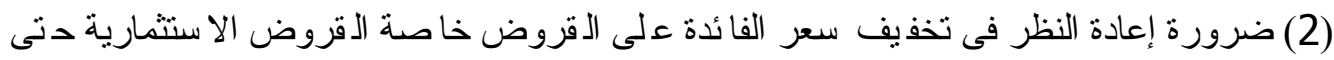
يستقيد منها الغالبية من الزراع.

(3) العمل على حل مشكلة المديونية الزر اعية و إز الة أسباب التعثر وذ للك بمتاب عة ومر اق بة القروض المنصرفة حتى تستخدم فى الغرض الذئ منحت من أجله.

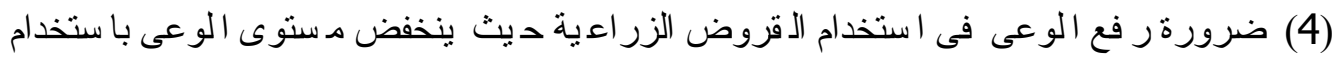
القروض فى الأر اضى الجديدة. (5) إعادة النظر فى قيمة القروض المدنوحة للمحاصيل المختلفة بالأر اضى الجد يدة حسب الإحتيا جات الفعلية لكل محصول بحيث تغطى التكاليف الإنتاجية.

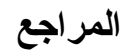

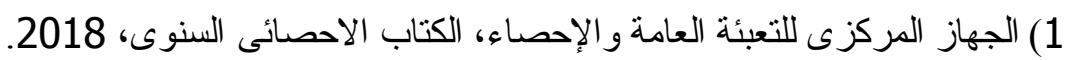

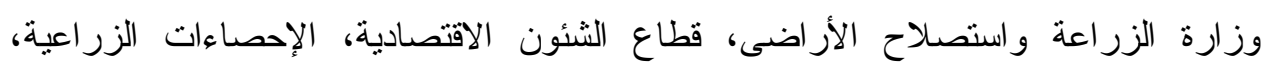
المحاصيل الصيفية و النيلية، 2016.

(3) خالد عزيز عبد السلام أحمد (دكتور)، وآخرون، المقدرة الائتمانية لمزارعى الأراضى الجديدة،

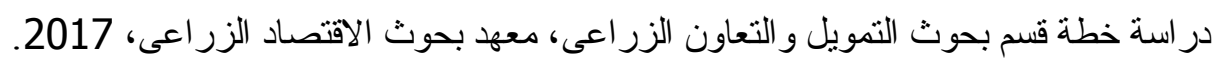

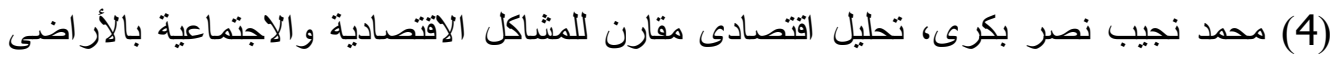
المسنصلحة الموزعة على الخريجين بمنطقتى (مريوط وشمال التحرير)، رسالة ماجسنير ، كلية

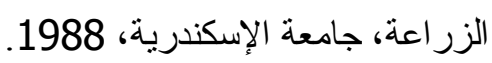

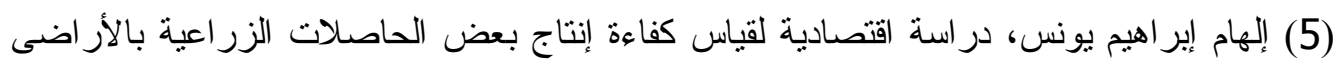

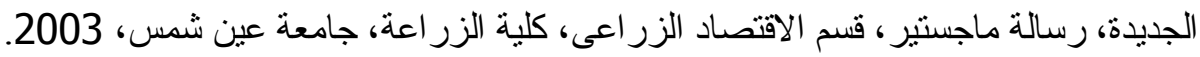

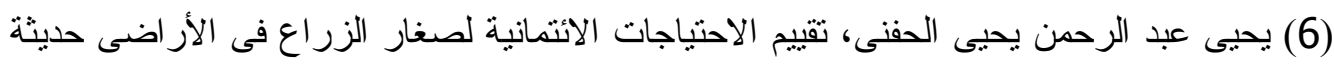

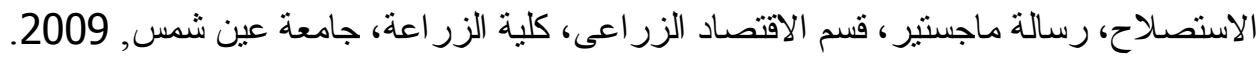

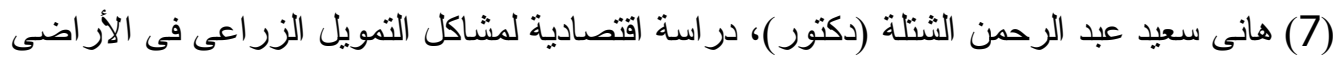
الجديدة، كلية الزراعة، جامعة المنوفية، مجلة المنوفية للبحوث الزر اعية، مجلد 33، العدد 1، الزية 